\title{
TRP channels in
}

\section{neurogastroenterology: opportunities for therapeutic intervention}

\author{
Werend Boesmans ${ }^{1}$, Grzegorz Owsianik ${ }^{2}$, Jan Tack ${ }^{1}$, Thomas Voets ${ }^{2}$ and \\ Pieter Vanden Berghe ${ }^{1}$
}

${ }^{1}$ TARGID - Translational Research Center for Gastrointestinal Disorders, KULeuven, Leuven, Belgium, and ${ }^{2}$ Laboratory of Ion Channel Research, KULeuven, Leuven, Belgium

\section{Correspondence}

Pieter Vanden Berghe, TARGID Translational Research Center for Gastrointestinal Disorders, KULeuven, Herestraat 49, Lab 701, B-3000 Leuven, Belgium. E-mail: pieter.vandenberghe@ med.kuleuven.be

\begin{abstract}
All drug target and ion channel nomenclature is conform to British Journal of Pharmacology's Guide to Receptors and Channels (GRAC) (Alexander et al., 2009).
\end{abstract}

\section{Keywords}

enteric nervous system; visceral afferents; gastrointestinal motility; sensory transmission; hypersensitivity; transient receptor potential cation channels

\section{Received}

17 February 2010

Revised

2 July 2010

Accepted

17 August 2010

The members of the superfamily of transient receptor potential (TRP) cation channels are involved in a plethora of cellular functions. During the last decade, a vast amount of evidence is accumulating that attributes an important role to these cation channels in different regulatory aspects of the alimentary tract. In this review we discuss the expression patterns and roles of TRP channels in the regulation of gastrointestinal motility, enteric nervous system signalling and visceral sensation, and provide our perspectives on pharmacological targeting of TRPs as a strategy to treat various gastrointestinal disorders. We found that the current knowledge about the role of some members of the TRP superfamily in neurogastroenterology is rather limited, whereas the function of other TRP channels, especially of those implicated in smooth muscle cell contractility (TRPC4, TRPC6), visceral sensitivity and hypersensitivity (TRPV1, TRPV4, TRPA1), tends to be well established. Compared with expression data, mechanistic information about TRP channels in intestinal pacemaking (TRPC4, TRPC6, TRPM7), enteric nervous system signalling (TRPCs) and enteroendocrine cells (TRPM5) is lacking. It is clear that several different TRP channels play important roles in the cellular apparatus that controls gastrointestinal function. They are involved in the regulation of gastrointestinal motility and absorption, visceral sensation and visceral hypersensitivity. TRP channels can be considered as interesting targets to tackle digestive diseases, motility disorders and visceral pain. At present, TRPV1 antagonists are under development for the treatment of heartburn and visceral hypersensitivity, but interference with other TRP channels is also tempting. However, their role in gastrointestinal pathophysiology first needs to be further elucidated.

\section{Abbreviations}

CGRP, calcitonin gene-related peptide; CNS, central nervous system; DRG, dorsal root ganglia; EC, enterochromaffin; EEC, enteroendocrine; EET, 5,6-epoxyeicosatrienoic acids; ENS, enteric nervous system; EPSP, excitatory postsynaptic potential; FD, functional dyspepsia; GABA, $\gamma$-aminobutyric acid; GI, gastrointestinal; IBD, inflammatory bowel disease; IBS, irritable bowel syndrome; ICC, interstitial cells of Cajal; IPAN, intrinsic primary afferent neuron; mGluR1, metabotropic glutamate receptor 1; MP, myenteric plexus; NG, nodose ganglion; PAR, protease-activated receptor; PLC, phospholipase C; SERCA, sarco/endoplasmic reticulum $\mathrm{Ca}^{2+}$-ATPase; SMP, submucosal plexus; TNBS, trinitrobenzene sulfonic acid; TRP, transient receptor potential; TRPA, Ankyrin TRP; TRPC, Canonical TRP; TRPM, Melastatin TRP; TRPML, Mucolipin TRP; TRPP, Polycystin TRP; TRPV, Vanilloid TRP 


\section{Introduction}

The gastrointestinal (GI) tract is the organ system that controls ingestion and digestion of food, absorption of nutrients, defense against pathogens and removal of indigestible remnants and waste products. Proper regulation of intestinal secretion, absorption, blood flow and motility requires a correct interplay of different humoral and cellular mechanisms including both intrinsic and extrinsic neuronal pathways.

The enteric nervous system (ENS) consists of an extensive neural network embedded in the wall of the gut and controls GI functioning to a large extent independently of the central nervous system (CNS). The ENS consists of different types of neurons and glia, generally organized in two nerve plexus (the myenteric plexus, MP and the submucosal plexus, SMP) with interconnected ganglia that extend along the length of the bowel (Furness, 2006). Interstitial cells of Cajal (ICC), situated at these plexus serve as pacemaker cells by producing rapidly rising, large potential changes that decrementally conduct into the intestinal smooth muscle syncitium (Kito et al., 2005), and are thereby responsible for the generation of intestinal slow waves (Ordog et al., 1999). Another type of ICC within the smooth muscle make close contact with nerve varicosities that innervate these muscle layers, and function as mediators of neuronal input (Faussone-Pellegrini et al., 1989; Burns et al., 1996; Ward et al., 2000). The output of the 'hard-wired' polysynaptic ENS circuits is reflected in the appropriate control of ICC activity, smooth muscle cell contraction or relaxation and secretion.

As a first and crucial step in the intrinsic control of GI function, the intestinal lumen is monitored by different types of enteroendocrine (EEC) cells, including enterochromaffin (EC) cells, scattered throughout the intestinal epithelium. Upon mechanical or chemical stimulation, EC cells release serotonin that activates mucosal processes of intrinsic primary afferent neurons (IPANs), which convey the signal to other neurons in the ENS (Gershon and Tack, 2007). However, this classic model of an intestinal 'reflex arc' in which IPANs serve as 'sensory' neurons has been challenged (Blackshaw et al., 2007). There is growing support for alternative sensory input to the network as different types of enteric neurons are also responsive to mechanical stimuli (Smith et al., 2007; Schemann and Mazzuoli, 2010). Wood (2008) suggested an alternative model by proposing that central pattern generators within the ENS activate the 'hard-wired' basic circuit in recurrent fashion independently of sensory input. As a result of millions of years of evolution and adaptive changes, GI motility is probably controlled by more than one mechanism. The ENS, the ICC network and the smooth muscle cells can therefore be considered as complementary and cooperating control systems that dominate each other depending on specific stimuli (Huizinga and Lammers, 2009). Modulation of either one of these complementary control systems trough intrinsic and extrinsic mediators or pathophysiological conditions will have a major impact on the net output of these integrating systems.

Apart from the intrinsic control of GI functions, there is also an important afferent nerve route, referred to as 'the gut-brain axis', that conveys sensory information to the CNS. Visceral afferent nerves follow two main pathways to the CNS. Vagal afferents have their cell bodies in the nodose ganglia (NG) and jugular ganglia and project centrally to the nucleus tractus solitarius. Spinal afferents, subdivided in splanchnic and pelvic afferents, generally follow the path of intestinal sympathetic and parasympathetic neurons and enter the CNS via the spinal cord. They have their cell bodies in the thoracolumbar and lumbosacral dorsal root ganglia (DRG) respectively. The sensory information conveyed by these visceral afferents is important for the central integration of gut sensation but also helps to coordinate the intrinsic control of gut reflex activity (Blackshaw et al., 2007). However, in diseased states such as inflammation, this information can be dramatically altered, possibly leading to visceral hypersensitivity and pain (Anand et al., 2007; Knowles and Aziz, 2009).

The mammalian transient receptor potential (TRP) superfamily comprises 28 TRP cation channels that can be subdivided into six main subfamilies: the TRPC (Canonical), TRPV (Vanilloid), TRPM (Melastatin), TRPA (Ankyrin), TRPML (Mucolipin) and the TRPP (Polycystin) channels (Ramsey et al., 2006). All TRPs are intrinsic membrane proteins composed of six putative transmembrane segments (S1-S6), cytosolic amino $(\mathrm{N})$ and carboxy $(\mathrm{C})$ termini with a variety of domains (e.g. ankyrin repeats, coiled coiled domains, calmodulin binding sites, etc.) (Owsianik et al., 2006). A putative cation-permeable pore region is located between transmembrane segments S5 and S6. Functional TRP channels form tetramers that are assembled from identical or similar TRP subunits. With exception of TRPM4 and TRPM5, all TRP channels are $\mathrm{Ca}^{2+}$-permeable cation channels. TRP channels can control cell functions by directly permitting $\mathrm{Ca}^{2+}$ influx into the cell in response to specific stimuli, or through depolarization of the membrane potential due to cation influx, and influence $\mathrm{Ca}^{2+}$ entry through other ion channels, such as voltage-gated $\mathrm{Ca}^{2+}$ channels (Nilius and 


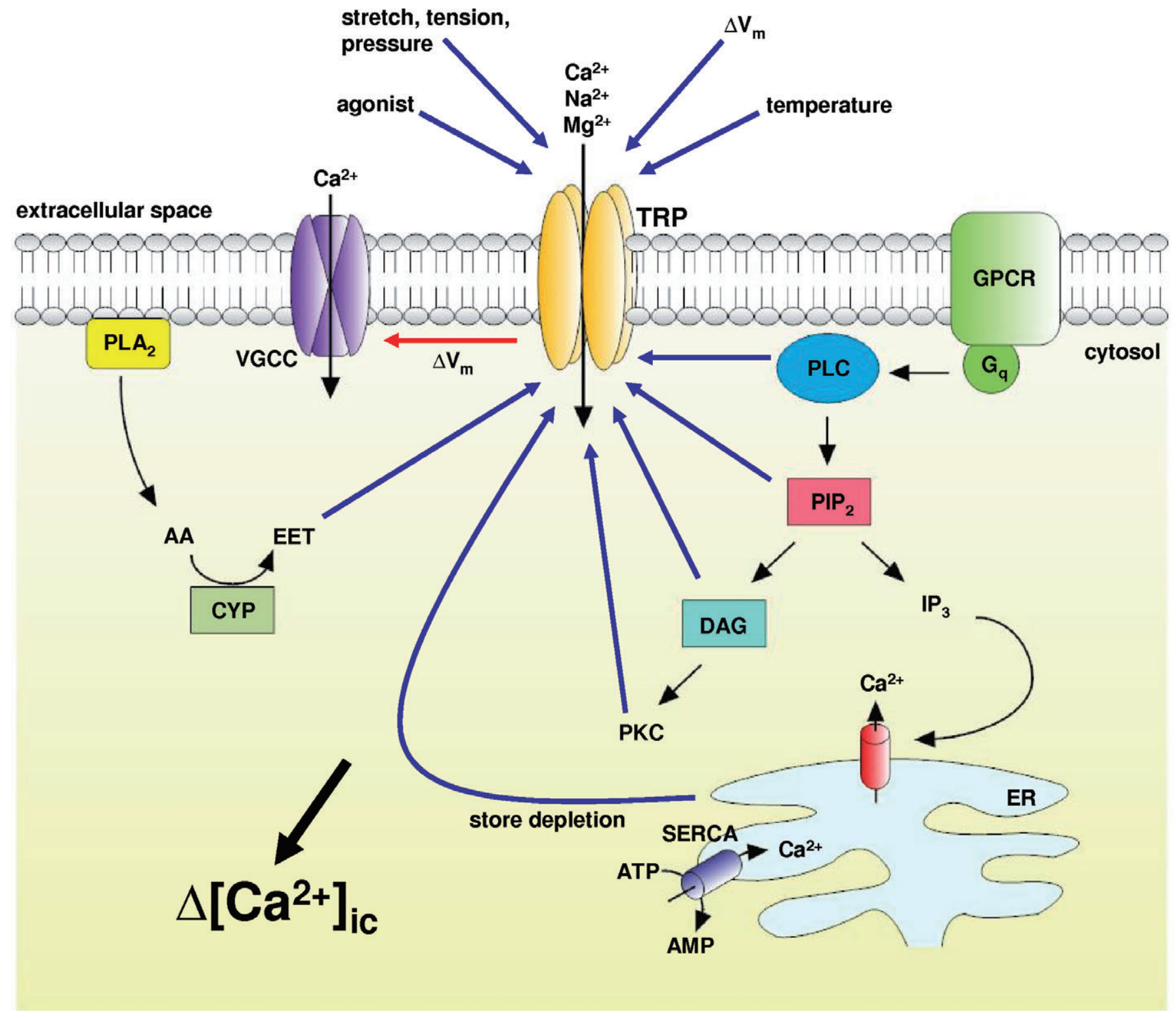

Figure 1

Schematic of the general activation mechanisms of the transient receptor potential (TRP) channels discussed in this review. TRPs are intrinsic membrane proteins that allow the passage of cations. Except for TRPM4 and TRPM5, all TRP channels are $\mathrm{Ca}^{2+}$-permeable cation channels but their selectivity for mono- and divalent cations varies greatly among different TRPs. The activation mechanism of TRP channels is unclear in many cases, but known activators include specific agonists such as capsaicin (TRPV1) and mustard oil (TRPA1), an increase in intracellular Ca ${ }^{2+}$ (TRPM4, 5), temperature (heat: TRPV1, 2, 3, 4, TRPM4, 5; cold: TRPM8, TRPA1), mechanical or osmotic stress (TRPV4, TRPCs?) and phospholipase C (PLC) activation. Cell swelling activates TRPV4 via the PLA 2 -pathway. G-protein-coupled receptor (GPCR) activation activates several TRP channels via PLC and diacylglycerol (DAG) dependent mechanisms. Intracellular $\mathrm{Ca}^{2+}$ also activates many TRP channels including TRPM5. TRPC3 and TRPC6 are activated by store depletion via a so far unknown mechanism. Several TRP channels are furthermore modulated by depolarization, temperature, intracellular phosphatidylinositol phosphates, such as $\mathrm{PI}(4,5) \mathrm{P}_{2}$, but also by inflammatory mediators and steroids. TRP channels control cell functions by directly permitting $\mathrm{Ca}^{2+}$ influx into the cell in response to specific stimuli, or through depolarization of the membrane potential due to cation influx. They can also influence $\mathrm{Ca}^{2+}$ entry through other ion channels, such as voltage-gated $\mathrm{Ca}^{2+}$ channels (VGCC). EET: 5,6epoxyeicosatrienoic acids; SERCA: sarco/endoplasmic reticulum $\mathrm{Ca}^{2+}$-ATPase. For more details, see text.

Voets, 2005). In many cases, the activation mechanism of TRP channels is unclear (Figure 1), but known activators include specific agonists such as mustard oil (TRPA1) and capsaicin (TRPV1), an increase in intracellular $\mathrm{Ca}^{2+}$ (TRPM4, 5), tempera- ture (heat: TRPV1, 2, 3, 4, TRPM4, 5; cold: TRPM8, TRPA1), mechanical or osmotic stress (TRPV4, TRPCs?) and phospholipase C (PLC) activation. TRP channel activity can be further modulated by intracellular phosphatidylinositol phosphates, such as 
$\mathrm{PI}(4,5) \mathrm{P}_{2}$ and membrane potential, but also by inflammatory mediators, cannabinoids and steroids (Nilius, 2007; Rohacs, 2007; Nilius and Voets, 2008).

Given the nature and action of the TRP channel family, these channels could well be involved in determining the final output of the intrinsic control machinery (ENS, ICC network and smooth muscle) by inducing subtle membrane potential changes. Accumulating evidence furthermore indicates that several of these TRP channels may be highly interesting targets to tackle GI diseases such as visceral hypersensitivity (as reviewed by Blackshaw et al., 2010).

In this review we discuss all mammalian subtypes but focus on those TRP channels, for which there is published evidence for their expression (functionally or the protein/mRNA level) and role in the GI tract. Specifically, we will discuss their function in the control of GI motility, ENS signalling and visceral sensitivity and provide our perspectives on pharmacological targeting of TRPs as a strategy to tackle GI diseases.

\section{TRPC channels}

The mammalian TRPC (canonical) subfamily shares most sequence homology with the first TRP channel cloned in drosophila (Montell and Rubin, 1989). TRPC channels function as receptor-operated nonselective $\mathrm{Ca}^{2+}$-permeable cation channels that cause membrane depolarization and entry of $\mathrm{Ca}^{2+}$ (Birnbaumer, 2009). TRPCs form both homomeric and heteromeric complexes (Strubing et al., 2001; 2003; Goel et al., 2002; Hofmann et al., 2002), which together with the likelihood that TRPCs also functionally overlap, made it difficult to assign specific functions to each of the channel subclasses. In general TRPC channels are activated via different isoforms of PLCs (Venkatachalam et al., 2002). TRPC1, TRPC4 and TRPC5 are activated by receptorinduced PLCs, but are in contrast to TRPC3, TRPC6 and TRPC7, completely unresponsive to diacylglycerol (Hofmann et al., 1999; Venkatachalam et al., 2003; Otsuguro et al., 2008). Several members of the TRPC subfamily can be found in the GI tract, but their role in the regulation of motility is only starting to be unravelled.

Immediately following the discovery of mammalian homologues of the drosophila TRP, TRPCs were postulated to be the ion channels responsible for the non-selective cationic conductance that had been recorded in many tissues. The pacemaker current displayed by the slow wave generating ICC in the GI tract was long believed to be initiated by such a voltage-independent, $\mathrm{Ca}^{2+}$-inhibited, non-selective cationic conductance. TRPC4, which was shown to be present in ICC together with TRPC6, was suggested to be a candidate for this current (Torihashi et al., 2002; Walker et al., 2002). Similar to the native pacemaker conductance, TRPC4 expressed in HEK293 cells was negatively regulated by $\mathrm{Ca}^{2+}$, activated by calmodulin inhibitors and had a similar single channel conductance (Walker et al., 2002). However, another group demonstrated that TRPC4 is activated by PLC and not by $\mathrm{Ca}^{2+}$ store depletion or decreases in intracellular $\mathrm{Ca}^{2+}$ (Lee et al., 2003a). Also the electrophysiological properties of TRPC4 are subject of debate. Freichel showed an inwardly rectifying current-voltage relationship for TRPC4 whereas Walker et al. described outwardly rectifying properties (Freichel, 2001; Walker et al., 2002). Furthermore, because it has been shown that TRPC4 knock-out mice display normal slow waves, TRPC4 appears not to be essential for pacemaker activity (Lee et al., 2005). The role of TRPC4 in ICC is still a matter of debate as evidence is accumulating that a $\mathrm{Cl}^{-}$current (via Ano1) may be responsible for slow wave initiation (Hwang etal., 2009; Zhu et al., 2009). TRPC4 was also suggested to be implicated in the neurogenic cholinergic control of GI smooth muscle cell contractility (Lee et al., 2005). This was further supported by Tsvilovskyy and colleagues who found expression of TRPC4 and TRPC6 channels in ileal smooth muscle cells. They show that TRPC 4 and TRPC 6 are gated by muscarinic receptors and are responsible for the muscarinic receptorinduced non-selective cation current that initially depolarizes intestinal smooth muscle cells leading to voltage-activated $\mathrm{Ca}^{2+}$ influx and smooth muscle cell contraction (the contribution of TRPC6 is significant but considerably smaller than that of TRPC4) (Tsvilovskyy et al., 2009).

TRPC4 and TRPC6 were also found in the guinea pig ENS. In the SMP, TRPC4/6 immunoreactivity was exclusively expressed by noncholinergic secretomotor neurons while it was present in a small population of both cholinergic and nitrergic neurons in the MP (Liu et al., 2008). TRPC4 could play a role in the release of $\gamma$-aminobutyric acid (GABA) from GABAergic nitrergic motor- and interneurons in the ENS (Williamson et al., 1996) by analogy with its role in dendritic GABA release by thalamic interneurons (Munsch et al., 2003).

TRPC1 immunoreactivity was found in cholinergic and noncholinergic secretomotor neurons in the SMP of the guinea pig ENS (Liu et al., 2008). Interestingly, TRPC1 mediates metabotropic glutamate receptor 1 (mGluR1)-induced slow excitatory postsynaptic currents in Purkinje neurons (Kim et al., 2003). Because mGluR1 is also expressed in submucous neurons of the ENS, it may be worth- 
while to investigate whether also here TRPC1 is involved in mGluR1-mediated, non-purinergic slow excitatory postsynaptic potentials displayed by some vasoactive-intestinal peptide positive secretomotor neurons in the guinea pig (Hu et al., 1999; Foong and Bornstein, 2009). In the MP, TRPC1 immunoreactivity is widely distributed and localized to neurons with a cholinergic, calretinin and nitrergic neurochemical phenotype.

Less information is available about the other members of the TRPC subfamily. TRPC2 mRNA was found in longitudinal muscle - myenteric plexus (LMMP) preparations and in isolated myenteric ganglia of guinea pig (Liu et al., 2008). However, TRPC2 is irrelevant in human physiology as its complete gene has been lost from the Old World monkey and human genomes, in which its remnants constitute a pseudogene (Yildirim and Birnbaumer, 2007). While TRPC3 mRNA and protein was also detected in LMMP, the SMP and myenteric ganglia, immunohistochemical analysis showed that TRPC3 immunoreactivity was exclusively expressed by neuropeptide $\mathrm{Y}$ immunoreactive neurons in the guinea pig SMP (Liu et al., 2008). TRPC5, which was also proposed as a candidate for muscarinic receptor activation induced nonselective cation current in murine stomach (Lee et al., 2003b), was found in LMMP, SMP and myenteric ganglia using both RT-PCR and Western blotting (Liu et al., 2008). Finally, TRPC7 is suggested to be present on GI smooth muscle (Walker et al., 2001; Liu et al., 2008).

Whether GI TRPC channels will become valid therapeutic targets awaits further clarification of their role in gut physiology and pathophysiology. However, the interference with smooth muscle TRPCs to modify contractility could particularly be interesting to treat various GI motility disorders.

For an overview, see Table 1.

\section{TRPV channels}

Six mammalian genes TRPV1-TRPV6 code for the members of the TRPV subfamily. These channels contain six ankyrin repeats in their cytosolic $\mathrm{N}$-termini. The first four (TRPV1-TRPV4) are polymodal thermo- and chemo-sensitive channels that are non-selective for cations and modestly permeable to $\mathrm{Ca}^{2+}$. On the other hand, TRPV5 and TRPV6 are highly $\mathrm{Ca}^{2+}$-selective channels and tightly regulated by intracellular $\left[\mathrm{Ca}^{2+}\right]$ (Nijenhuis et al., 2005). For detailed reviews about the members of the TRPV subfamily, see following reviews ( $\mathrm{O}^{\prime}$ Neil and Heller, 2005; Vennekens et al., 2008; Vriens et al., 2009).

\section{Table 1}

TRPC channels in neurogastroenterology

\begin{tabular}{|cll|}
\hline & Proposed location & Proposed function \\
TRPC1 & $\begin{array}{c}\text { Enteric neurons of the } \\
\text { SMP and MP }\end{array}$ & $\begin{array}{c}\text { mGluR1-induced slow } \\
\text { EPSPs }\end{array}$ \\
TRPC2 & LMMP, MP & $?$ \\
TRPC3 & SMP, MP, NPY neurons & $?$ \\
TRPC4 & ICC, smooth muscle, & Pacemaker current, \\
& noncholinergic & muscarinic receptor- \\
& secretomotor neurons & induced smooth muscle \\
& in the SMP, enteric & cell depolarization, \\
& neurons in the MP & GABA release \\
TRPC5 & SMP, MP, smooth muscle & $\begin{array}{c}\text { Muscarinic } \\
\text { receptor-induced }\end{array}$ \\
& & smooth muscle cell \\
& & depolarization \\
TRPC6 & ICC, smooth muscle, & $\begin{array}{c}\text { Muscarinic } \\
\text { receptor-induced }\end{array}$ \\
& SMP, MP & smooth muscle cell \\
& & depolarization
\end{tabular}

EPSP, excitatory postsynaptic potential; GABA, $\gamma$-aminobutyric acid; ICC, interstitial cell of Cajal; LMMP, longitudinal musclemyenteric plexus; mGluR1, metabotropic glutamate receptor 1 ; MP, myenteric plexus; NPY, neuropeptide Y; SMP, submucosal plexus.

TRPV1, the founding member of the mammalian TRPV channels, is predominantly expressed on unmyelinated and some thinly myelinated sensory neurons that can be activated by capsaicin, noxious heat, acidosis $(\mathrm{pH}<5.9)$, depolarization and endovanilloids (Caterina etal., 1997; Tominaga et al., 1998; Voets et al., 2004). Apart from signalling to the CNS, activation of TRPV1 on these afferents also provokes local efferent-like effects that control peripheral effector mechanisms, GI motility and secretion via the release of tachykinins and calcitonin gene-related peptide (CGRP) (Holzer, 1988; 2006; Bartho et al., 1992; Bartho and Holzer, 1995; de Man et al., 2008).

Several inflammatory mediators and factors associated with hyperalgesia (e.g. bradykinin, 5-HT, neuronal growth factor, tryptase), but also mild acidosis are able to sensitize TRPV1 and enhance the probability of channel gating by heat and capsaicin (Chuang et al., 2001; Ji et al., 2002; Amadesi et al., 2004; 2006; Sugiuar et al., 2004). Because TRPV1 was suggested to play a crucial role in nociception based on its expression on mostly unmyelinated visceral afferents (Ward et al., 2003; Brierley et al., 2005; Christianson et al., 2006), a vast number of studies investigating its role in visceral sensation and pain emerged (Caterina et al., 2000). (Reviews by Di 
Marzo et al., 2002; Geppetti and Trevisani, 2004; Holzer, 2008b; Blackshaw et al., 2010).

Animal experiments have demonstrated an important role for TRPV1 both in gastro-esophageal (Bielefeldt and Davis, 2008), small intestinal (Rong et al., 2004) and colonic (Jones et al., 2005) visceral mechanosensitivity as well as in hypersensitivity induced by intracolonic administration of zymosan (Jones et al., 2007) or neonatal irritation of the colon (Winston et al., 2007). In addition, TRPV1 was shown to be up-regulated in nociceptive visceral afferents of rodents with experimental trinitrobenzene sulfonic acid (TNBS)-induced colitis (Miranda et al., 2007; De Schepper et al., 2008a). De Schepper et al. showed that acute TNBS-induced colitis increased the response to colorectal distention in rat pelvic afferent $\mathrm{C}$ fibres but not in A $\delta$ fibres. This inflammation-induced increase in mechanosensitivity was reduced by the TRPV1 antagonist BCTC (De Schepper et al., 2008b). Intriguingly, and indicative of the controversy in this area of research, a similar in vivo study by Sengupta et al. did not demonstrate any change in mechanosensitivity after TNBSinduced colitis (Sengupta et al., 1999). In agreement with the latter study, mechanosensitivity of nociceptive serosal and mesenteric colonic splanchnic afferents to graded stimuli was shown to be unaffected during dextran sulfate sodium colitis in rats (Phillis et al., 2009). However, TRPV1 seems to be an important amplifier of noxious stimuli as the antagonist SB-750364 inhibited mechanosensitivity and spontaneous neuronal discharge only during inflammation but not in healthy conditions (Phillis et al., 2009). Taken together, it could well be that the effect of TRPV1 antagonists may only become significant after TRPV1 up-regulation, which is not necessarily associated with obvious inflammation. In rats, stress-induced visceral hypersensitivity that is dependent on mast cell degranulation and subsequent TRPV1 activation also occurs in the absence of overt inflammation (van den Wijngaard et al., 2009). Similarly, up-regulation of TRPV1 in visceral afferents has also been observed without overt inflammation as is typical of patients with irritable bowel syndrome (IBS) (Akbar et al., 2008).

As far as human tissue is concerned, altered TRPV1 expression on nerve fibres has been demonstrated in biopsies from patients with rectal hypersensitivity (Chan et al., 2003) or inflammatory bowel disease (IBD) (Yiangou et al., 2001) and shown to correlate with the degree of abdominal pain in IBS (Akbar et al., 2008). By infusing capsaicin in the human small intestine, enhanced chemonociception in functional dyspepsia (FD) patients compared with controls has been reported (Schmidt et al., 2004; Hammer et al., 2008). It is unclear whether TRPV1 receptors contribute to symptom generation in FD, either indirectly through sensitization of mechanosensitive afferents, or directly, through activation by luminal factors such as gastric acid. Symptomatic benefit of long-term administration of capsaicin tablets was also shown in FD and attributed to desensitization of gastric nociceptive C-type fibres (Bortolotti et al., 2002). This 'desensitization' is most probably caused by defunctionalization or ablation of sensory afferent fibres due to repeated stimulation of TRPV1 (Holzer, 2008a).

TRPV1-expressing afferents also innervate the esophagus. Here, TRPV1 immunoreactivity is increased in mucosal biopsies from patients with erosive (Matthews et al., 2004) and non-erosive esophagitis (Bhat and Bielefeldt, 2006) and it is expected that TRPV1 also plays a key role in the pathogenesis of symptoms associated with reflux (Ang et al., 2008). In keeping with this hypothesis, intra-esophageal capsaicin installation was found to induce symptoms of heartburn and chest pain in healthy volunteers (Kindt et al., 2009). The proposed role of TRPV1 is further supported by a recent study showing that acid-induced activation of TRPV1 receptors in feline esophageal mucosa results in substance $P$ and CGRP release, presumably arising from submucous neurons, together with the release of platelet activating factor from esophageal epithelial cells, which also turned out to express TRPV1 (Cheng et al., 2009). The release of proinflammatory mediators via TRPV1 activation probably also plays a role in acid-induced esophagitis because TRPV1 null mice develop less severe esophagitis compared with wild-type mice (Fujino et al., 2006). Based on these observations, TRPV1 antagonists are under development for the treatment of heartburn and visceral hypersensitivity, among other therapeutic targets (Gunthorpe and Szallasi, 2008). Although hyperthermia was reported with several TRPV1 antagonists, there is new evidence that TRPV1 antagonists that are devoid of this adverse effect can be synthesized. It is, however, still too early to make conclusions regarding their efficacy (Khairatkar-Joshi and Szallasi, 2009). Crucial in the current drug development for TRPV1 antagonists that is aimed at dissociating hyperthermia effects from anti-hyperalgesic efficacy, is to differentiate between the physiological role and pathological manifestation of TRPV1. Specific intervention with the latter population is definitely of high interest from a therapeutic point of view (Holzer, 2008a).

Apart from its presence on esophageal epithelial cells, TRPV1 was also found to be expressed in human gastric oxyntic cells and mucous secreting epithelial cells in the rat stomach (Nozawa et al., 2001; Kato et al., 2003; Faussone-Pellegrini et al., 
2005). Together with neuronal mechanisms, this particular epithelial location of TRPV1 is suggested to be involved in the regulation of gastric chlorhydropeptic secretion (Raybould and Tache, 1989; Horie et al., 2004; Faussone-Pellegrini et al., 2005).

Taken together, these data all point to an important role for TRPV1 in the modulation of mechanosensitivity, chemosensitivity and pain in pathological states. However, some controversy about the details of TRPV1's involvement in mechanosensation and nociception in different models still exists. Questions as to whether increased TRPV1 function during inflammation is due to higher open probability of the channel leading in turn to increased responses to inflammatory mediators such as 5-HT will need to be determined in future studies (Sugiuar et al., 2004; Coldwell et al., 2007). Also the interaction of TRPV1 with other signalling systems, especially the protease-activated receptor (PAR) has to be addressed in more detail (Amadesi et al., 2004; 2006). Also the relationship between TRPV1 and the cannabinoid system in the GI tract (Sanger, 2007) is of increasing interest as it has been shown that endocannabinoids are produced within the ENS (Boesmans et al., 2009; Hong et al., 2009). Interference with TRPV1 function for pure analgesic purposes furthermore warrants a better understanding of the physiological role of TRPV1 in other than neuronal tissues (Wong and Gavva, 2009).

TRPV4 is another member of the TRPV subfamily that is also implicated in mechanosensation and pain (Alessandri-Haber et al., 2003; Suzuki et al., 2003a). The channel can be activated by endogenously produced 5,6-epoxyeicosatrienoic acid, an arachidonic acid metabolite (Watanabe et al., 2003), as well as by the synthetic phorbol ester $4 \alpha$-phorbol 12,13-didecanoate (Watanabe et al., 2002), bisandrographolide A (Smith et al., 2006) and by physical stimuli (Vriens etal., 2004). The channel is expressed in sensory neurons and TRPV4 null mice display decreased cutaneous pain and an increased threshold for somatic mechanical nociception, all of which firmly links TRPV4 to mechanotransduction (Suzuki et al., 2003a,b; Grant et al., 2007).

However, apart from its role in somatic nociception, recent evidence also points towards a role for TRPV4 in visceral nociception (Blackshaw et al., 2010). Brierley et al. investigated whether TRPV4expressing serosal and mesenteric afferents in the colon were visceral nociceptors (Brierley et al., 2008). Consistent with the expression of TRPV4 on visceral nerve endings, they found that mechanosensory responses of these afferents were dramatically reduced in TRPV4-deficient mice, while vagal and pelvic mucosal and muscular afferents showed no deficit. Because the effect of a non-selective TRP channel blocker ruthenium red, known to reduce mechanosensitivity of the presumed visceral nociceptors, was completely lost in TRPV4 null mice, it is conceivable that these neurons exclusively use TRPV4, and no other TRP channels, for their mechanosensation. Cenac et al. also showed that TRPV4 activation by $4 \alpha$-phorbol 12,13-didecanoate causes visceral allodynia and hyperalgesia and using a siRNA approach, they also demonstrated that TRPV4 is involved in visceral nociception in response to colorectal distention (Cenac et al., 2008). Similar to its expression in mice, TRPV4 immunoreactivity was also found in the human colon, and was suggested to be enriched in resections from IBD patients (Brierley et al., 2008). If expression is indeed increased in Crohn's disease and/or ulcerative colitis, the TRPV4 channel should be further explored as a target for pain relief in these patients.

PAR2 activation, which is implicated in the generation of visceral hypersensitivity by mediators released from colonic biopsies of patients with IBS (Cenac et al., 2007; Buhner et al., 2009), potentiates the response of cultured DRG neurons on TRPV4 agonists (Grant et al., 2007). In agreement, Cenac et al. and Sipe et al. furthermore showed that PAR2induced hypersensitivity is mediated by the activation of TRPV4 (Cenac et al., 2008; Sipe et al., 2008). TRPV 4 and PAR2 are co-expressed on the majority of spinal afferents innervating the murine colon and TRPV4 deletion or antagonism completely abolishes the sensitizing effects of PAR2 activation in these neurons (Sipe et al., 2008). However, because PAR2induced $\mathrm{Ca}^{2+}$ transients were not inhibited by TRPV4-targeted siRNA in DRG neurons, parallel, yet incremental, pathways for PAR2 and TRPV4 are suggested at the cellular level (Cenac et al., 2008). These observations suggest that TRPV4 can be considered a therapeutic target in GI disorders that involve elevated production or release of proteases, such as IBS (Roka et al., 2008). Apart from neuronal expression, TRPV4 is also expressed by brush-bordered epithelial cells but its function in the mucosa has not been addressed (Cenac et al., 2008). Interestingly, PAR4 was recently shown to counterbalance TRPV4 and PAR2 elicited allodynia and hyperalgesia (Auge et al., 2009). Auge et al. demonstrated that PAR4 is present on murine colonic afferents expressing both PAR2 and TRPV4. Intracolonic administration of a subinflammatory dose of a PAR4 agonist reduced the visceromotor response to colorectal distention and inhibited visceral hyperalgesia induced by PAR2 or TRPV4 activation (Auge et al., 2009).

TRPV2 is expressed in TRPV1-negative thinly myelinated neurons of rat DRG, TG and NG (Caterina et al., 1999; Ichikawa and Sugimoto, 2003; 
Table 2

TRPV channels in neurogastroenterology

\begin{tabular}{|c|c|c|}
\hline & Proposed location & Proposed function \\
\hline TRPV1 & $\begin{array}{l}\text { Visceral afferents, } \\
\text { esophageal epithelial } \\
\text { cells, oxyntic cells }\end{array}$ & $\begin{array}{l}\text { Visceral chemo-, } \\
\text { mechano-and } \\
\text { nociception, ? }\end{array}$ \\
\hline TRPV2 & $\begin{array}{l}\text { TRPV1-negative visceral } \\
\text { afferents, enteric } \\
\text { neurons in the SMP } \\
\text { and MP }\end{array}$ & $?$ \\
\hline TRPV4 & $\begin{array}{l}\text { Visceral afferents, } \\
\text { epithelial cells }\end{array}$ & $\begin{array}{l}\text { Visceral mechanosensation } \\
\text { and nociception,? }\end{array}$ \\
\hline TRPV5, 6 & Epithelium & $\mathrm{Ca}^{2+}$ absorption \\
\hline
\end{tabular}

MP, myenteric plexus; SMP, submucosal plexus.

Lewinter et al., 2004; Zhang et al., 2004) and is activated, at least in rodents, by noxious heat $\left(>52^{\circ} \mathrm{C}\right)$. Kashiba et al. found TRPV2-positive neurons in the rat MP and SMP, some of which were also immunoreactive for $\mathrm{Ca}^{2+}$-binding protein calbindin (Kashiba et al., 2004). However, calbindin is not a conclusive marker for IPANs in the rat ENS, therefore the claim that these neurons are intrinsic sensory neurons remains speculative. Because heat stimuli above $52^{\circ} \mathrm{C}$ are highly unlikely to occur in the gut, a role in mechanosensation as proposed by Muraki is more likely in the gut (Muraki et al., 2003). However, while heat and mechano-activation of TRPV2 remain controversial, the channel is consistently activated by 2-aminoethoxydiphenyl borate and tetra-hydrocannabinol, the psychoactive compound in marijuana (Neeper et al., 2007). Future studies will have to provide insight into the role of TRPV2 in the gut.

At present, there is no evidence for expression of TRPV3 in the gut. The last two members of the TRPV family (TRPV5 and TRPV6) are mainly involved in $\mathrm{Ca}^{2+}$ absorption across epithelial cells (Suzuki et al., 2008). TRPV5 and TRPV6 are located on the brush border membrane of enterocytes and are considered rate-limiting in active intestinal $\mathrm{Ca}^{2+}$ absorption (Hoenderop and Bindels, 2008). Mice lacking TRPV6 display a $60 \%$ decrease in intestinal $\mathrm{Ca}^{2+}$ absorption, lower bone mineral density, deficient weight gain and decreased fertility (Bianco et al., 2007). For an overview, see Table 2 .

\section{TRPM channels}

The TRPM family consists of eight different channels, TRPM1-TRPM8. TRPM channels exhibit highly variable permeability to $\mathrm{Ca}^{2+}$ and $\mathrm{Mg}^{2+}$, ranging from
$\mathrm{Ca}^{2+}$ impermeable (TRPM4, 5) to highly $\mathrm{Ca}^{2+}$ and $\mathrm{Mg}^{2+}$ permeable (TRPM6, 7). Contrary to TRPCs and TRPVs, TRPMs do not contain ankyrin repeats within their N-terminal domain. The main characteristics of the different members of the TRPM subfamily have been reviewed extensively (Aarts and Tymianski, 2005; Kraft and Harteneck, 2005; McNulty and Fonfria, 2005).

TRPM5 is a highly temperature-sensitive, heatactivated channel expressed in taste cells of the tongue and is involved in the signal transduction of sweet, bitter and umami tastes (Zhang et al., 2003; Talavera et al., 2005; Damak et al., 2006). Downstream of the taste receptor, an increase in intracellular $\mathrm{Ca}^{2+}$ leads to TRPM5 activation, which in turn enhances membrane depolarization and signal propagation by synaptic transmission or paracrine peptide release. It is proposed that nutrient sensing in the GI tract resembles taste signalling on the tongue (Rozengurt and Sternini, 2007; Sternini et al., 2008). Indeed, together with other taste signalling molecules, TRPM5 is expressed in epithelial cells of the gut (Bezencon et al., 2007; Jang et al., 2007; Young et al., 2009), and similar to their function in lingual taste cells, the GI taste signalling elements also respond to tastants in the gut lumen (Jang et al., 2007; Margolskee et al., 2007). TRPM5 is shown to be present in human duodenal L cells, where its expression is inversely related to the blood glucose concentration at least in subjects with type 2 diabetes (Jang et al., 2007; Young et al., 2009). However, important species differences do exist as in the murine gut TRPM5 is not colocalized with any of the classical markers for EEC cells such as chromogranin A, 5-HT, glucagon-like peptide 1, ghrelin and cholecystokinin (Bezencon et al., 2007; 2008; Kokrashvili et al., 2009). In mouse, TRPM5 is mostly expressed in brush cells (Kaske et al., 2007; Bezencon et al., 2008), also referred to as tufted or caveolated cells (Sbarbati and Osculati, 2005a,b; Morroni et al., 2007). Recently, it has been shown to be essential for the release of endogenous opioids from duodenal epithelial cells that contain enkaphelin and uroguanilyn (Kokrashvili et al., 2009).

Apart from TRPC4 and TRPC6 (see above), also TRPM7 was suggested to be involved in the pacemaker current of ICC. Kim et al. demonstrated that TRPM7 is expressed in murine ICC and that the cation selectivity of pacemaker currents in primary cultured ICC was similar to that of TRPM7 (Kim et al., 2005). Targeting TRPM7 using a RNA interference approach, resulted in inhibition of pacemaking activity. TRPM7 is, however, best described for its role in cell viability and magnesium homeostasis (Nadler et al., 2001; Schmitz et al., 2003; Jin et al., 2008). Therefore, skepticism has arisen regarding 
the effect of siRNA experiments on cell viability and subsequent loss of pacemaker current (Farrugia and Kraichely, 2005).

Another member of the TRP family, TRPM8, initially identified in prostate cancer (Tsavaler et al., 2001), is expressed in DRG, TG and in papillae of the tongue and can be activated by cooling and menthol (McKemy et al., 2002; Peier et al., 2002). Mice lacking TRPM8 exhibit deficient behavioural responses to cold temperatures (Bautista et al., 2007; Colburn et al., 2007; Dhaka et al., 2007). Mint leaves have been used for ages because of their therapeutic and soothing effects. The ancient Romans, for example, chewed mint leaves to freshen their breath after a meal but also to aid digestion. Peppermint oil, with menthol as major constituent, reduces gastric spasms and slows small intestinal transit (Goerg and Spilker, 2003; Hiki et al., 2003). Menthol is also present in herbal drugs designed to treat abdominal discomfort and pain (Schemann et al., 2006; von Arnim et al., 2007; Pilichiewicz et al., 2007). The concept of using naturally occurring TRPM8 ligands, such as menthol, to inhibit hypermotility states is attractive. However, the expression and role of TRPM8 in the GI tract and its involvement in the clinical effects of herbal medicines are still controversial. TRPM8 mRNA was detected in the fundus (and colon) of rat and was implicated in cooling-induced contractions of fundic muscle strips (Mustafa and Oriowo, 2005). Zhang et al. also found TRPM8 mRNA in murine NG, small intestinal and stomach mucosa but Penuelas et al. failed to confirm its expression although the same primer pairs were used (Zhang et al., 2004; Penuelas et al., 2007). The latter group also showed that menthol produces slow but long-lasting relaxations of the mouse colon and consequently concluded this phenomenon to be TRPM8-independent (Penuelas et al., 2007).

The role of TRPM6 in the GI tract is well established. TRPM6 is important for $\mathrm{Mg}^{2+}$ absorption across intestinal epithelial cells and hypomagnesaemia with secondary hypocalcemia is one of the best studied channelopathies so far (Quamme, 2008).

Given the high number of mast cells in the gut wall, TRPM4 might sensitize or modulate visceral afferent activity. In mice lacking TRPM4, bone marrow-derived mast cells had augmented degranulation and released more histamine, leukotrienes and tumour necrosis factor due to increased $\mathrm{Ca}^{2+}$ entry after FcepsilonRI stimulation (Vennekens et al., 2007). TRPM4 is also involved in the migration of bone marrow-derived mast cells by regulation of $\mathrm{Ca}^{2+}$-dependent actin cytoskeleton rearrangements (Vennekens et al., 2007; Shimizu
Table 3

TRPM channels in neurogastroenterology

\begin{tabular}{|c|c|c|}
\hline & Proposed location & Proposed function \\
\hline TRPM4 & Mast cells & $\begin{array}{l}\text { Migration and degranulation } \\
\text { of mast cells. }\end{array}$ \\
\hline TRPM5 & EEC cells, brush cells & $\begin{array}{l}\text { Nutrient sensing, release of } \\
\text { endogenous opioids. }\end{array}$ \\
\hline TRPM6 & Epithelium & $\mathrm{Mg}^{2+}$ absorption \\
\hline TRPM7 & ICCs & Pacemaker current \\
\hline TRPM8 & Visceral afferents & ? \\
\hline
\end{tabular}

EEC, enteroendocrine; ICC, interstitial cell of Cajal.

et al., 2009). TRPM4 could be considered a therapeutic target in GI disorders that involve mast cell activation/degranulation, such as food allergies, mastocytosis and IBS (Bischoff, 2009). For an overview, see Table 3 .

\section{TRPA1}

The TRPA family contains only one mammalian member, TRPA1. The channel contains 14-16 NH2 terminal ankyrin repeats (Story et al., 2003), an unusual structural feature that might be relevant to its proposed mechano-sensory role (Nagata et al., 2005). TRPA 1 is activated by noxious cold (17 \pm $1^{\circ} \mathrm{C}$ ) and is present on sensory neurons, primarily in subsets expressing TRPV1 (Story et al., 2003; Bandell et al., 2004; Nagata et al., 2005; Bautista et al., 2006; Karashima et al., 2009). Activation of TRPA1 represents, together with TRPM8 activity, the main mechanism underlying cold sensing (Dhaka et al., 2006; Wrigley et al., 2009). Chemical activators of TRPA1 include isothiocyanates (the pungent compounds in mustard oil, wasabi and horseradish), methyl salicylate (in winter green oil), cinnamaldehyde (in cinnamon), allicin and diallyl disulphide (in garlic), acrolein (an irritant in exhaust fumes and teargas), nicotine, menthol and tetrahydrocannabinol (Bandell et al., 2004; Jordt et al., 2004; Macpherson et al., 2005; Bautista et al., 2006; Karashima et al., 2007; Talavera et al., 2009). For a more detailed review, see (McMahon and Wood, 2006).

TRPA1 was found to be present in vagal, splanchnic and pelvic visceral afferents in mouse (Brierley et al., 2009; Cattaruzza et al., 2009), rat (Kondo et al., 2009) and guinea pig (Yu and Ouyang, 2009; Yu et al., 2009). It is mainly expressed in afferents with mucosal and serosal/mesenteric mechanoreceptive fields (Brierley et al., 2009) and 
colocalization with CGRP, substance $\mathrm{P}$, tyrosine kinase A and TRPV1 was described (Brierley et al., 2009; Cattaruzza et al., 2009; Kondo et al., 2009). Recent observations indicate that the mechanosensory function is altered in specific subtypes of visceral afferents of TRPA1 knock-out mice (Brierley et al., 2009). TRPA1 thus contributes to the detection of low- and high-intensity mechanical stimuli depending on the afferent ending in which they are expressed. Especially the involvement of TRPA1 in low-intensity mechanical stimuli ( tactile) is surprising as TRPA1 was believed to be only involved in noxious stimuli (Kwan et al., 2006). The role of TRPA1 in visceral mechanosensation was also explored in the stomach of rats where gastric distention induced ERK1/2 activation in TRPA1 expressing DRG and NG neurons. Interestingly, antisense knock-down of TRPA1 suppressed this activation in DRG, but not in NG neurons (Kondo et al., 2009).

Together with the recent documentation of the mechanosensory function of TRPA1, also its role in visceral hypersensitivity is extensively studied (Blackshaw et al., 2010). TRPA1 agonists induce mechanical hypersensitivity, which is exacerbated in inflammatory conditions, as seen after TNBS treatment (Brierley et al., 2009; Cattaruzza et al., 2009) but is not involved in distention-induced pain in mice under basal conditions (Cattaruzza et al., 2009). The channel is furthermore shown to play a pivotal role in bradykinin-induced mechanical hypersensitivity but does not contribute to the actual bradykinin-induced responses (Brierley et al., 2009; Yu and Ouyang, 2009). Yu et al. recently demonstrated that TRPA1 plays an important role in mast cell activation-induced long-lasting mechanical hypersensitivity of vagal nodose C-fibres in the guinea-pig esophagus (Yu et al., 2009). Mast cell tryptase-induced PAR2 activation is proposed as a mechanism for TRPA1 sensitization, which was confirmed by Cattaruzza et al. who showed that PARinduced hyperalgesia was absent in TRPA1 null mice (Cattaruzza et al., 2009). However, PAR2 activation did not change mechanosensory function in mice lacking TRPA1 in the study by Brierley and colleagues. Moreover, the TRPA1-deficient afferents in these mice also showed similar responses to PAR2 activation compared with wild-type afferents (Brierley et al., 2009). Similarly as for TRPV channels, some controversy about the involvement of PAR2 still exists. Whether regional differences (colonic/ splanchnic vs. esophageal/vagal), species differences (guinea pig vs. mouse) or different background of TRPA1-deficient mice are the source of these opposing observations has to be subject of further research. If confirmed in humans, the involvement of TRPA1 in mechanosensitivity would make this a target to consider in disorders characterized by enhanced mechanosensitivity, which is the case in many functional GI disorders (Anand et al., 2007).

Apart from visceral afferents, expression of TRPA1 was also found in human and rat EC cells, in which TRPA1 agonists cause $\mathrm{Ca}^{2+}$ influx and 5-HT release (Nozawa et al., 2009). It is proposed that TRPA1 agonists delay gastric emptying via such serotonergic mechanisms (Doihara et al., 2009). In an earlier study, TRPA1 mRNA was also detected in human and mouse mucosa (Purhonen et al., 2008). Although functional data were obtained from the neuroendocrine cell line STC-1, here TRPA1 was suggested to play a role in intestinal cholecystokinin release.

Evidence also points to a role for TRPA1 in the intrinsic neurons of the ENS. TRPA1 immunoreactive fibres were found in the rat MP (Kondo et al., 2009) and mRNA was detected in the isolated smooth muscle layer of rat small intestine (Nozawa et al., 2009). TRPA1 agonists were furthermore shown to promote contraction of isolated strips of mouse colon (Penuelas et al., 2007). However, mouse colonic compliance did not change by applying mustard oil or after TRPA1 deletion (Cattaruzza et al., 2009).

\section{TRPML and TRPP channels}

The TRPML family contains three mammalian members (TRPML1-3). TRPML channels are expressed by intracellular endosomes and lysosomes and interact with a variety of vesicular proteins. Although functional studies suggest that TRPMLs play active roles in membrane fusion and fission, signal transduction and vesicular homeostasis, the exact mechanisms have not been elucidated (Cheng et al., 2010).

The TRPP family was named after its founding member, polycystin kidney disease- 2 , a gene product mutated in many cases of autosomal dominant polycystic kidney disease and comprises three channel-like and five non-channel members (Delmas, 2005). They are believed to function independently or together as part of a multiprotein receptor/ion-channel complex, and are suggested to be involved in transducing $\mathrm{Ca}^{2+}$-dependent mechanosensitive signals in response to cilia bending in renal epithelial and endodermally derived cells.

It is not known whether TRPML and TRPP channels are expressed in the GI tract. Consequently, relevance for a specific function for members of the TRPML and TRPP subfamilies in neurogastroenterology has not been reported. 


\section{Concluding remarks}

Several animal and human studies have provided a vast amount of data indicating that TRP channels are present at almost all levels of GI control, yet their exact role remains rather elusive in most cases (Figure 2). Although it is clear that several TRP superfamily members play an important part in the control of GI motility, also here, mechanistic information about their modus operandi is still limited. The contribution of TRPC4 and TRPC6 in muscarinic receptor-induced contractility is quite well established while the role of TRPC1, TRPC2 and TRPA1 in intrinsic enteric neurons and the role of TRPC4 and TRPM7 in the generation of ICC pacemaker currents require further studies. Apart from motility control, TRP channels are also involved in epithelial functions. TRPM5 is, similar as in taste cells of the tongue, believed to play a role in taste signalling by EEC cells and brush cells in the gut. Serotonin release by EC cells and chlorhydropeptic secretion by parietal cells is suggested to be controlled by TRPA1 and TRPV1 respectively. The latter is furthermore proposed to play a role in acid sensing by esophageal epithelial cells. Because TRP channels are involved in many different aspects of sensory perception such as cold/heat, pressure/ tension and pain, their role in sensation via visceral afferents and other sensory cell types present in the GI tract is not that surprising. Visceral mechano-, chemo-, thermo- and nociception are indeed shown to be mediated by TRPV1, TRPV4 and TRPA1 (and probably also TRPM8) channels. Importantly, in diseased states such as inflammation these channels are also implicated in visceral hypersensitivity and pain, sometimes even more pronounced than in healthy conditions.

Besides their sensitivity to physical and thermal stimuli, many of the TRP channels are sensitive to plant metabolites. Several of the noxious components that activate TRP channels are part of defence mechanisms that plants have developed against herbivores (Vriens et al., 2008). Because many of these plant derivatives are present in food, GI cells become readily exposed. Spices like mint, mustard, pepper, cinnamon and garlic are known to affect TRP channels, which in most cases is likely to underlie their effects on the alimentary tract. A better understanding of TRP channel expression and function is essential to fully exploit the use of these simple food additives and comprehend their mechanism of action.

With respect to the regulation of GI motility, several TRP channels can be regarded as possible pharmaceutical targets as they are likely to modulate and gently tilt the balance to increase or decrease activity that is already endogenously present in the regulatory network of enteric neurons, ICC and smooth muscle cells. Reducing the increased sensory perception caused by visceral hypersensitivity in GI diseases such as IBD, IBS and FD is another area where TRP channels could be targeted with TRPV1 agonists the first ones being studied (Holzer, 2008b; Blackshaw et al., 2010), and where the TRPV4 receptor may also be a target worth considering. Except for the agents targeting TRPV1, treatment of human GI diseases with TRP channel-related drugs is still in its infancy; therefore future studies are needed to specifically elucidate the pathophysiological role of TRP channels. As has been suggested in the case of TRPV1 (Holzer, 2008a), identifying the difference between such 'pathological' TRP channels and TRPs needed for normal GI physiology, will be crucial. Given the widespread expression and roles of TRP channels in both the gut and the rest of the body, specific targeting of these 'pathological' TRPs will be very challenging. In addition, the discovery of more specific and suitable ligands is warranted as well as a better understanding of the interaction with other signalling systems.

Indeed, TRP channel signalling is often clearly influenced by other signalling cascades. One such a signalling system already touched upon is the family of PARs. Proteases released from colonic biopsies of IBS patients have been shown to induce visceral hypersensitivity in mice via increased activity of PAR2 (Cenac et al., 2007). An increasing amount of evidence indicates that these proteases induce hypersensitivity via the modulation of TRP channels. Especially, advances in the understanding of how PAR2 sensitizes TRPV1 brought up possible mechanisms by which inflammatory pain occurs. For example, the temperature of activation of TRPV1 is well below body temperature in the presence of PAR2 (Amadesi et al., 2004) and in pulmonary vagal afferents, it has been shown that PAR2 increases the open probability of TRPV1 ( $\mathrm{Gu}$ and Lee, 2009). Thus, PAR2 reduces the activation threshold for this receptor and therefore potentially leads to spontaneous pain sensation. A striking similarity, however, exists in how different TRP channels interact with PAR2. As apart from TRPV1, also TRPV4 and TRPA1 are suggested to interact with PAR2, interesting questions about this similarity have risen: Does PAR2-mediated sensitization of TRPA1 (Dai et al., 2007) also involve an increase of TRPA1 open probability? Is the mechanism of action by which PAR2 interacts with TRPV4 similar? Answering these questions will not be trivial as some conflicting observations have been reported for instance in case of the TRPA1 and PAR2 interaction (Brierley et al., 2009; Cattaruzza et al., 2009). 


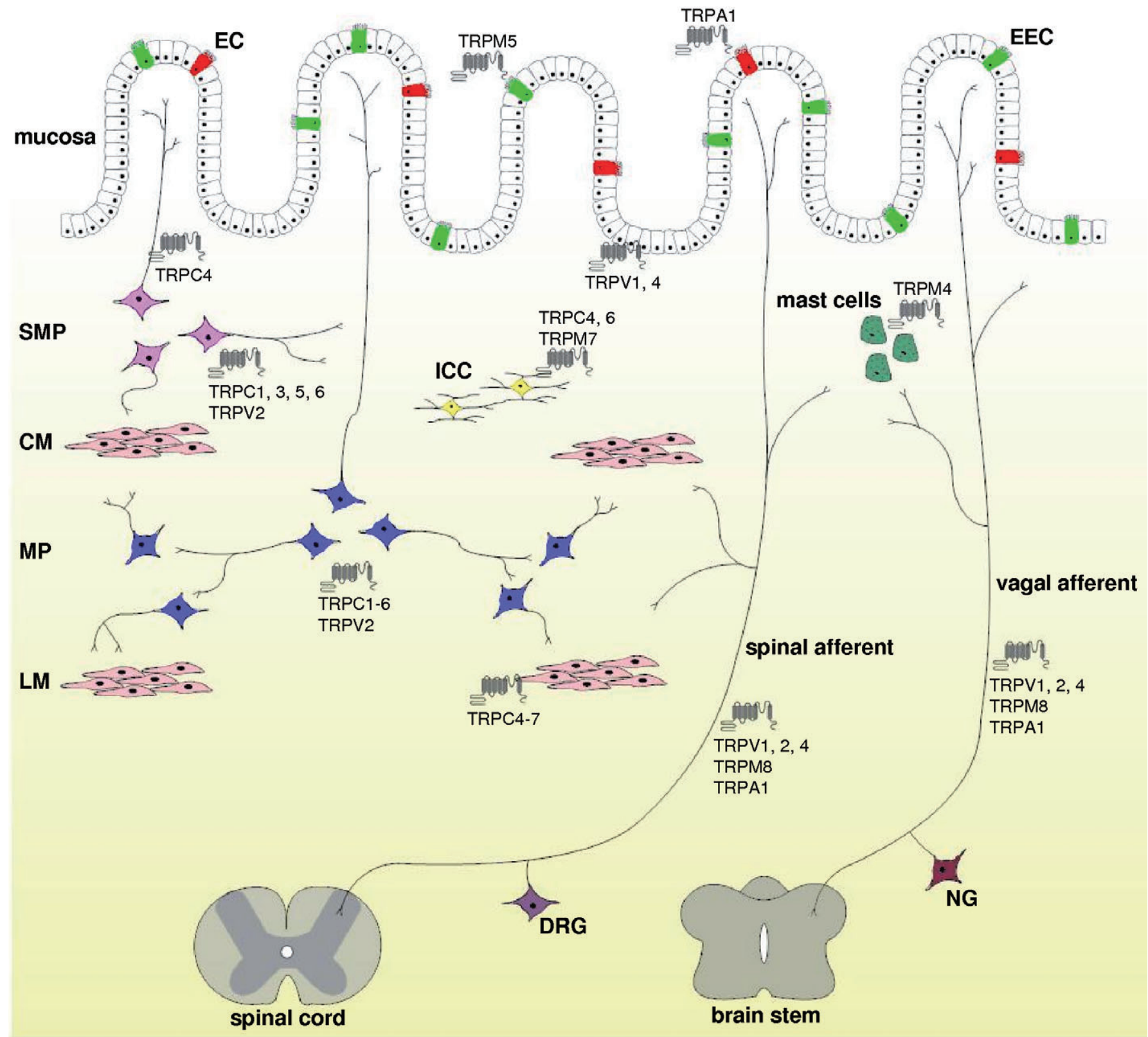

\section{Figure 2}

Schematic overview of transient receptor potential (TRP) channel distribution in the gastrointestinal (GI) tract. TRP channels can be found at almost all levels of $\mathrm{Gl}$ control but their role remains rather elusive in most cases. In the GI mucosa, TRPs are expressed by enterocytes and different types of enteroendocrine (EEC, green) cells including enterochromaffin (EC, red) cells. They are involved in several epithelial functions such as nutrient sensing (TRPM5) and chlorhydropeptic secretion (TRPV1). Some TRP channels, especially TRPCs, are expressed by subtypes of enteric neurons in both the myenteric (MP, blue) and submucosal plexus (SMP, pink), yet knowledge about their function in the enteric nervous system is limited. Smooth muscle cells in the circular (CM) and longitudinal muscle (LM) layers also express TRPCs. More specifically, TRPC4 and TRPC6 play a role in muscarinic receptor-induced smooth muscle cell depolarization. Together with TRPM7, TRPC4 and TRPC6 are also implicated in the generation of pacemaker currents by interstitial cells of Cajal (ICC, yellow) but their exact function in the generation of slow waves is still debated. Apart from being involved in the intrinsic control of Gl functions, a vast amount of data also points to a crucial role for TRP channels in visceral sensation by extrinsic afferents. Especially TRPs that are involved in different aspects of sensory perception such as temperature, pressure and pain are expressed by both spinal (purple) and vagal (maroon) afferents. TRPV1, 2, 4, TRPA1 and TRPM8 channels are shown to mediate visceral mechano-, chemo-, thermo- and nociception and are also implicated in visceral hypersensitivity in diseased states such as irritable bowel syndrome. The role of TRPM4 also deserves attention because factors released by these cells influence hypersensitivity to a large extent. For more details, see text. 
Next to PAR2, there is also evidence that PAR4 is involved in the modulation of visceral nociception. This particular receptor would rather inhibit the PAR2-induced visceral hypersensitivity or downregulate TRPV4 agonist-induced signalling. Because mustard oil-provoked visceral pain was reduced in PAR4-deficient mice, TRPA1 activity is probably also reduced by PAR4 (Auge et al., 2009) but whether PAR4 likewise reduces the open probability of TRPV1 remains to be elucidated.

Although it is known that various TRP subunits can form heteromers (Schaefer, 2005), it is not clear whether certain pathological conditions induce particular heteromers to be formed. Functional interaction between different members of the TRP family could also be a possible mechanism via which visceral pain is mediated.

Overall, we conclude that the presence of TRP channels at almost all levels of GI control points at their involvement in gut homeostasis. Several TRP superfamily members play an important part in the control of GI motility and visceral sensation. They are also implicated in visceral hypersensitivity and pain but the exact role of most of them still remains rather elusive. Hence, it is obvious that TRP channels can be regarded as new targets for pharmacological intervention in the treatment of GI diseases. However, a substantial amount of work is still necessary to fully understand their mechanism of action. Nonetheless, thanks to the increasing number of publications in this field, as illustrated in this review, we consider this possible in the near future.

\section{Acknowledgements}

This work was supported by grants from the Belgian Ministry for Science Policy (Interuniversity Attraction Pole, IUAP P6/28), the Research FoundationFlanders (FWO G.0172.03, G.0565.07 and G.0501.10) and the Research Council of the KULeuven (Methusalem program, GOA 2004/07 and $\mathrm{EF} / 95 / 010)$.

\section{Statement of conflict of interest}

The authors have nothing to declare.

\section{References}

Aarts MM, Tymianski M (2005). TRPMs and neuronal cell death. Pflugers Arch 451: 243-249.
Akbar A, Yiangou Y, Facer P, Walters JR, Anand P, Ghosh S (2008). Increased capsaicin receptor TRPV1-expressing sensory fibres in irritable bowel syndrome and their correlation with abdominal pain. Gut 57: 923-929.

Alessandri-Haber N, Yeh JJ, Boyd AE, Parada CA, Chen X, Reichling DB et al. (2003). Hypotonicity induces TRPV4-mediated nociception in rat. Neuron 39: 497-511.

Alexander SPH, Mathie A, Peters JA (2009). Guide to Receptors and Channels (GRAC), 4th edition. Br J Pharmacol 158 (Suppl. 1): S1-S254.

Amadesi S, Nie J, Vergnolle N, Cottrell GS, Grady EF, Trevisani M et al. (2004). Protease-activated receptor 2 sensitizes the capsaicin receptor transient receptor potential vanilloid receptor 1 to induce hyperalgesia. J Neurosci 24: 4300-4312.

Amadesi S, Cottrell GS, Divino L, Chapman K, Grady EF, Bautista F et al. (2006). Protease-activated receptor 2 sensitizes TRPV1 by protein kinase Cepsilonand A-dependent mechanisms in rats and mice. J Physiol 575: 555-571.

Anand P, Aziz Q, Willert R, van Oudenhove L (2007). Peripheral and central mechanisms of visceral sensitization in man. Neurogastroenterol Motil 19 (Suppl. 1): 29-46.

Ang D, Sifrim D, Tack J (2008). Mechanisms of heartburn. Nat Clin Pract Gastroenterol Hepatol 5: 383-392.

von Arnim U, Peitz U, Vinson B, Gundermann KJ, Malfertheiner P (2007). STW 5, a phytopharmacon for patients with functional dyspepsia: results of a multicenter, placebo-controlled double-blind study. Am J Gastroenterol 102: 1268-1275.

Auge C, Balz-Hara D, Steinhoff M, Vergnolle N, Cenac N (2009). Protease-activated receptor-4 (PAR 4): a role as inhibitor of visceral pain and hypersensitivity. Neurogastroenterol Motil 21: 1189-e1107.

Bandell M, Story GM, Hwang SW, Viswanath V, Eid SR, Petrus MJ et al. (2004). Noxious cold ion channel TRPA1 is activated by pungent compounds and bradykinin. Neuron 41: 849-857.

Bartho L, Holzer P (1995). The inhibitory modulation of guinea-pig intestinal peristalsis caused by capsaicin involves calcitonin gene-related peptide and nitric oxide. Naunyn Schmiedebergs Arch Pharmacol 353: 102-109.

Bartho L, Koczan G, Holzer P, Maggi CA, Szolcsanyi J (1992). Antagonism of the motor effects of CGRP and of capsaicin on the guinea pig ileum by human CGRP8-37. Ann N Y Acad Sci 657: 538-540.

Bautista DM, Jordt SE, Nikai T, Tsuruda PR, Read AJ, Poblete $\mathrm{J}$ et al. (2006). TRPA1 mediates the inflammatory actions of environmental irritants and proalgesic agents. Cell 124: 1269-1282. 
Bautista DM, Siemens J, Glazer JM, Tsuruda PR, Basbaum AI, Stucky CL et al. (2007). The menthol receptor TRPM8 is the principal detector of environmental cold. Nature 448: 204-208.

Bezencon C, le Coutre J, Damak S (2007). Taste-signaling proteins are coexpressed in solitary intestinal epithelial cells. Chem Senses 32: 41-49.

Bezencon C, Furholz A, Raymond F, Mansourian R, Metairon S, Le Coutre J et al. (2008). Murine intestinal cells expressing Trpm5 are mostly brush cells and express markers of neuronal and inflammatory cells. J Comp Neurol 509: 514-525.

Bhat YM, Bielefeldt K (2006). Capsaicin receptor (TRPV1) and non-erosive reflux disease. Eur J Gastroenterol Hepatol 18: 263-270.

Bianco SD, Peng JB, Takanaga H, Suzuki Y, Crescenzi A, Kos CH et al. (2007). Marked disturbance of calcium homeostasis in mice with targeted disruption of the Trpv6 calcium channel gene. J Bone Miner Res 22: 274-285.

Bielefeldt K, Davis BM (2008). Differential effects of ASIC3 and TRPV1 deletion on gastroesophageal sensation in mice. Am J Physiol Gastrointest Liver Physiol 294: G130-G138.

Birnbaumer L (2009). The TRPC class of ion channels: a critical review of their roles in slow, sustained increases in intracellular $\mathrm{Ca}(2+)$ concentrations. Annu Rev Pharmacol Toxicol 49: 395-426.

Bischoff SC (2009). Physiological and pathophysiological functions of intestinal mast cells. Semin Immunopathol 31: 185-205.

Blackshaw LA, Brookes SJ, Grundy D, Schemann M (2007). Sensory transmission in the gastrointestinal tract. Neurogastroenterol Motil 19 (Suppl. 1): 1-19.

Blackshaw LA, Brierley SM, Hughes PA (2010). TRP channels: new targets for visceral pain. Gut 59: 126-135.

Boesmans W, Ameloot K, van den Abbeel V, Tack J, Vanden Berghe P (2009). Cannabinoid receptor 1 signalling dampens activity and mitochondrial transport in networks of enteric neurones. Neurogastroenterol Motil 21: 958-977.

Bortolotti M, Coccia G, Grossi G, Miglioli M (2002). The treatment of functional dyspepsia with red pepper. Aliment Pharmacol Ther 16: 1075-1082.

Brierley SM, Carter R, Jones W 3rd, Xu L, Robinson DR, Hicks GA et al. (2005). Differential chemosensory function and receptor expression of splanchnic and pelvic colonic afferents in mice. J Physiol 567: 267-281.

Brierley SM, Page AJ, Hughes PA, Adam B, Liebregts T, Cooper NJ et al. (2008). Selective role for TRPV4 ion channels in visceral sensory pathways. Gastroenterology 134: 2059-2069.

Brierley SM, Hughes PA, Page AJ, Kwan KY, Martin CM, O'Donnell TA et al. (2009). The ion channel TRPA1 is required for normal mechanosensation and is modulated by Algesic stimuli. Gastroenterology 137: 2084-2095.
Buhner S, Li Q, Vignali S, Barbara G, De Giorgio R, Stanghellini V et al. (2009). Activation of human enteric neurons by supernatants of colonic biopsy specimens from patients with irritable bowel syndrome. Gastroenterology 137: 1425-1434.

Burns AJ, Lomax AE, Torihashi S, Sanders KM, Ward SM (1996). Interstitial cells of Cajal mediate inhibitory neurotransmission in the stomach. Proc Natl Acad Sci USA 93: 12008-12013.

Caterina MJ, Schumacher MA, Tominaga M, Rosen TA, Levine JD, Julius D (1997). The capsaicin receptor: a heat-activated ion channel in the pain pathway. Nature 389: 816-824.

Caterina MJ, Rosen TA, Tominaga M, Brake AJ, Julius D (1999). A capsaicin-receptor homologue with a high threshold for noxious heat. Nature 398: 436-441.

Caterina MJ, Leffler A, Malmberg AB, Martin WJ, Trafton J, Petersen-Zeitz KR et al. (2000). Impaired nociception and pain sensation in mice lacking the capsaicin receptor. Science 288: 306-313.

Cattaruzza F, Spreadbury I, Miranda-Morales M, Grady EF, Vanner SJ, Bunnett NW (2009). Transient receptor potential Ankyrin-1 has a major role in mediating visceral pain in mice. Am J Physiol Gastrointest Liver Physiol 298: G81-G91.

Cenac N, Andrews CN, Holzhausen M, Chapman K, Cottrell G, Andrade-Gordon P et al. (2007). Role for protease activity in visceral pain in irritable bowel syndrome. J Clin Invest 117: 636-647.

Cenac N, Altier C, Chapman K, Liedtke W, Zamponi G, Vergnolle N (2008). Transient receptor potential vanilloid-4 has a major role in visceral hypersensitivity symptoms. Gastroenterology 135: 937-946.

Chan CL, Facer P, Davis JB, Smith GD, Egerton J, Bountra C et al. (2003). Sensory fibres expressing capsaicin receptor TRPV1 in patients with rectal hypersensitivity and faecal urgency. Lancet 361: 385-391.

Cheng L, Monte S, Ma J, Hong J, Tong M, Cao W et al. (2009). HCl-activated neural and epithelial vanilloid receptors (TRPV1) in cat esophageal mucosa. Am J Physiol Gastrointest Liver Physiol 297: G135-G143.

Cheng X, Shen D, Samie M, Xu H (2010). Mucolipins: intracellular TRPML1-3 channels. FEBS Lett 584: 2013-2021.

Christianson JA, Traub RJ, Davis BM (2006). Differences in spinal distribution and neurochemical phenotype of colonic afferents in mouse and rat. J Comp Neurol 494: 246-259.

Chuang HH, Prescott ED, Kong H, Shields S, Jordt SE, Basbaum AI et al. (2001). Bradykinin and nerve growth factor release the capsaicin receptor from PtdIns(4,5)P2-mediated inhibition. Nature 411: 957-962.

Colburn RW, Lubin ML, Stone DJ Jr, Wang Y, Lawrence D, D'Andrea MR et al. (2007). Attenuated cold sensitivity in TRPM8 null mice. Neuron 54: 379-386. 
Coldwell JR, Phillis BD, Sutherland K, Howarth GS, Blackshaw LA (2007). Increased responsiveness of rat colonic splanchnic afferents to 5-HT after inflammation and recovery. J Physiol 579: 203-213.

Dai Y, Wang S, Tominaga M, Yamamoto S, Fukuoka T, Higashi T et al. (2007). Sensitization of TRPA1 by PAR2 contributes to the sensation of inflammatory pain. J Clin Invest 117: 1979-1987.

Damak S, Rong M, Yasumatsu K, Kokrashvili Z, Perez CA, Shigemura N et al. (2006). Trpm5 null mice respond to bitter, sweet, and umami compounds. Chem Senses 31: 253-264.

De Schepper HU, De Man JG, Ruyssers NE, Deiteren A, Van Nassauw L, Timmermans JP et al. (2008a). TRPV1 receptor signaling mediates afferent nerve sensitization during colitis-induced motility disorders in rats. Am J Physiol Gastrointest Liver Physiol 294: G245-G253.

De Schepper HU, De Winter BY, Van Nassauw L, Timmermans JP, Herman AG, Pelckmans PA et al. (2008b). TRPV1 receptors on unmyelinated C-fibres mediate colitis-induced sensitization of pelvic afferent nerve fibres in rats. J Physiol 586: 5247-5258.

Delmas P (2005). Polycystins: polymodal receptor/ion-channel cellular sensors. Pflugers Arch 451: 264-276.

Dhaka A, Viswanath V, Patapoutian A (2006). Trp ion channels and temperature sensation. Annu Rev Neurosci 29: 135-161.

Dhaka A, Murray AN, Mathur J, Earley TJ, Petrus MJ, Patapoutian A (2007). TRPM8 is required for cold sensation in mice. Neuron 54: 371-378.

Di Marzo V, Blumberg PM, Szallasi A (2002). Endovanilloid signaling in pain. Curr Opin Neurobiol 12: $372-379$.

Doihara H, Nozawa K, Kawabata-Shoda E, Kojima R, Yokoyama T, Ito H (2009). TRPA1 agonists delay gastric emptying in rats through serotonergic pathways. Naunyn Schmiedebergs Arch Pharmacol 380: 353-357.

Farrugia G, Kraichely RE (2005). Deciphering the molecular basis for the pacemaker signal.

Gastroenterology 129: 1787-1789.

Faussone-Pellegrini MS, Pantalone D, Cortesini C (1989). An ultrastructural study of the interstitial cells of Cajal of the human stomach. J Submicrosc Cytol Pathol 21: $439-460$

Faussone-Pellegrini MS, Taddei A, Bizzoco E, Lazzeri M, Vannucchi MG, Bechi P (2005). Distribution of the vanilloid (capsaicin) receptor type 1 in the human stomach. Histochem Cell Biol 124: 61-68.

Foong JPP, Bornstein JC (2009). mGluR1 receptors contribute to non-purinergic slow excitatory transmission to submucosal VIP neurons of guinea-pig ileum. Front Neurosci 3: 46. DOI: 10.3389/neuro.21. 001.2009 .

Freichel M (2001). Lack of an endothelial store-operated $\mathrm{Ca} 2+$ current impairs agonist-dependent vasorelaxation in TRP4(-/-) mice. Nature Cell Biology 3: 121-127.
Fujino K, de la Fuente SG, Takami Y, Takahashi T, Mantyh CR (2006). Attenuation of acid induced oesophagitis in VR-1 deficient mice. Gut 55: 34-40.

Furness JB (2006). The Enteric Nervous System. Blackwell Pub.: Malden, MA.

Geppetti P, Trevisani M (2004). Activation and sensitisation of the vanilloid receptor: role in gastrointestinal inflammation and function. Br J Pharmacol 141: 1313-1320.

Gershon MD, Tack J (2007). The serotonin signaling system: from basic understanding to drug development for functional GI disorders. Gastroenterology 132: 397-414.

Goel M, Sinkins WG, Schilling WP (2002). Selective association of TRPC channel subunits in rat brain synaptosomes. J Biol Chem 277: 48303-48310.

Goerg KJ, Spilker T (2003). Effect of peppermint oil and caraway oil on gastrointestinal motility in healthy volunteers: a pharmacodynamic study using simultaneous determination of gastric and gall-bladder emptying and orocaecal transit time. Aliment Pharmacol Ther 17: 445-451.

Grant AD, Cottrell GS, Amadesi S, Trevisani M, Nicoletti P, Materazzi S et al. (2007). Protease-activated receptor 2 sensitizes the transient receptor potential vanilloid 4 ion channel to cause mechanical hyperalgesia in mice. J Physiol 578: 715-733.

Gu Q, Lee LY (2009). Effect of protease-activated receptor 2 activation on single TRPV1 channel activities in rat vagal pulmonary sensory neurons. Exp Physiol 94: 928-936.

Gunthorpe MJ, Szallasi A (2008). Peripheral TRPV1 receptors as targets for drug development: new molecules and mechanisms. Curr Pharm Des 14: 32-41.

Hammer J, Fuhrer M, Pipal L, Matiasek J (2008). Hypersensitivity for capsaicin in patients with functional dyspepsia. Neurogastroenterol Motil 20: $125-133$.

Hiki N, Kurosaka H, Tatsutomi Y, Shimoyama S, Tsuji E, Kojima J et al. (2003). Peppermint oil reduces gastric spasm during upper endoscopy: a randomized, double-blind, double-dummy controlled trial. Gastrointest Endosc 57: 475-482.

Hoenderop JG, Bindels RJ (2008). Calciotropic and magnesiotropic TRP channels. Physiology 23: 32-40.

Hofmann T, Obukhov AG, Schaefer M, Harteneck C, Gudermann T, Schultz G (1999). Direct activation of human TRPC6 and TRPC3 channels by diacylglycerol. Nature 397: 259-263.

Hofmann T, Schaefer M, Schultz G, Gudermann T (2002). Subunit composition of mammalian transient receptor potential channels in living cells. Proc Natl Acad Sci USA 99: 7461-7466.

Holzer P (1988). Local effector functions of capsaicin-sensitive sensory nerve endings: involvement of tachykinins, calcitonin gene-related peptide and other neuropeptides. Neuroscience 24: 739-768. 
Holzer P (2006). Efferent-like roles of afferent neurons in the gut: blood flow regulation and tissue protection. Auton Neurosci 125: 70-75.

Holzer P (2008a). The pharmacological challenge to tame the transient receptor potential vanilloid-1 (TRPV1) nocisensor. Br J Pharmacol 155: 1145-1162. Holzer P (2008b). TRPV1: a new target for treatment of visceral pain in IBS? Gut 57: 882-884.

Hong S, Fan J, Kemmerer ES, Evans S, Li Y, Wiley JW (2009). Reciprocal changes in vanilloid (TRPV1) and endocannabinoid (CB1) receptors contribute to visceral hyperalgesia in the water avoidance stressed rat. Gut 58: 202-210.

Horie S, Yamamoto H, Michael GJ, Uchida M, Belai A, Watanabe $\mathrm{K}$ et al. (2004). Protective role of vanilloid receptor type 1 in $\mathrm{HCl}$-induced gastric mucosal lesions in rats. Scand J Gastroenterol 39: 303-312.

Hu HZ, Ren J, Liu S, Gao C, Xia Y, Wood JD (1999). Functional group I metabotropic glutamate receptors in submucous plexus of guinea-pig ileum. Br J Pharmacol 128: $1631-1635$

Huizinga JD, Lammers WJ (2009). Gut peristalsis is governed by a multitude of cooperating mechanisms. Am J Physiol Gastrointest Liver Physiol 296: G1-G8.

Hwang SJ, Blair PJ, Britton FC, O’Driscoll KE, Hennig G, Bayguinov YR et al. (2009). Expression of anoctamin 1/TMEM16A by interstitial cells of Cajal is fundamental for slow wave activity in gastrointestinal muscles. J Physiol 587: 4887-4904.

Ichikawa H, Sugimoto T (2003). The co-expression of VR1 and VRL-1 in the rat vagal sensory ganglia. Brain Res 980: 293-296.

Jang HJ, Kokrashvili Z, Theodorakis MJ, Carlson OD, Kim BJ, Zhou J et al. (2007). Gut-expressed gustducin and taste receptors regulate secretion of glucagon-like peptide-1. Proc Natl Acad Sci USA 104: 15069-15074.

Ji RR, Samad TA, Jin SX, Schmoll R, Woolf CJ (2002). p38 MAPK activation by NGF in primary sensory neurons after inflammation increases TRPV1 levels and maintains heat hyperalgesia. Neuron 36: 57-68.

Jin J, Desai BN, Navarro B, Donovan A, Andrews NC, Clapham DE (2008). Deletion of Trpm7 disrupts embryonic development and thymopoiesis without altering Mg2+ homeostasis. Science 322: 756-760.

Jones RC 3rd, Xu L, Gebhart GF (2005). The mechanosensitivity of mouse colon afferent fibers and their sensitization by inflammatory mediators require transient receptor potential vanilloid 1 and acid-sensing ion channel 3. J Neurosci 25: 10981-10989.

Jones RC 3rd, Otsuka E, Wagstrom E, Jensen CS, Price MP, Gebhart GF (2007). Short-term sensitization of colon mechanoreceptors is associated with long-term hypersensitivity to colon distention in the mouse. Gastroenterology 133: 184-194.

Jordt SE, Bautista DM, Chuang HH, McKemy DD, Zygmunt PM, Hogestatt ED et al. (2004). Mustard oils and cannabinoids excite sensory nerve fibres through the TRP channel ANKTM1. Nature 427: 260-265.
Karashima Y, Damann N, Prenen J, Talavera K, Segal A, Voets $\mathrm{T}$ et al. (2007). Bimodal action of menthol on the transient receptor potential channel TRPA1. J Neurosci 27: 9874-9884.

Karashima Y, Talavera K, Everaerts W, Janssens A, Kwan KY, Vennekens R et al. (2009). TRPA1 acts as a cold sensor in vitro and in vivo. Proc Natl Acad Sci USA 106: 1273-1278.

Kashiba H, Uchida Y, Takeda D, Nishigori A, Ueda Y, Kuribayashi K et al. (2004). TRPV2-immunoreactive intrinsic neurons in the rat intestine. Neurosci Lett 366: 193-196.

Kaske S, Krasteva G, Konig P, Kummer W, Hofmann T, Gudermann T et al. (2007). TRPM5, a taste-signaling transient receptor potential ion-channel, is a ubiquitous signaling component in chemosensory cells. BMC Neurosci 8: 49.

Kato S, Aihara E, Nakamura A, Xin H, Matsui H, Kohama K et al. (2003). Expression of vanilloid receptors in rat gastric epithelial cells: role in cellular protection. Biochem Pharmacol 66: 1115-1121.

Khairatkar-Joshi N, Szallasi A (2009). TRPV1 antagonists: the challenges for therapeutic targeting. Trends Mol Med 15: 14-22.

Kim SJ, Kim YS, Yuan JP, Petralia RS, Worley PF, Linden DJ (2003). Activation of the TRPC1 cation channel by metabotropic glutamate receptor mGluR1. Nature 426: 285-291.

Kim BJ, Lim HH, Yang DK, Jun JY, Chang IY, Park CS et al. (2005). Melastatin-type transient receptor potential channel 7 is required for intestinal pacemaking activity. Gastroenterology 129: 1504-1517.

Kindt S, Vos R, Blondeau K, Tack J (2009). Influence of intra-oesophageal capsaicin instillation on heartburn induction and oesophageal sensitivity in man. Neurogastroenterol Motil 21: 1032-e1082.

Kito Y, Ward SM, Sanders KM (2005). Pacemaker potentials generated by interstitial cells of Cajal in the murine intestine. Am J Physiol Cell Physiol 288: C710-C720.

Knowles CH, Aziz Q (2009). Basic and clinical aspects of gastrointestinal pain. Pain 141: 191-209.

Kokrashvili Z, Rodriguez D, Yevshayeva V, Zhou H, Margolskee RF, Mosinger B (2009). Release of endogenous opioids from duodenal enteroendocrine cells requires Trpm5. Gastroenterology 137: 598-606.

Kondo T, Obata K, Miyoshi K, Sakurai J, Tanaka J, Miwa H et al. (2009). Transient receptor potential A1 mediates gastric distention-induced visceral pain in rats. Gut 58: 1342-1352.

Kraft R, Harteneck C (2005). The mammalian melastatin-related transient receptor potential cation channels: an overview. Pflugers Arch 451: 204-211.

Kwan KY, Allchorne AJ, Vollrath MA, Christensen AP, Zhang DS, Woolf CJ et al. (2006). TRPA1 contributes to cold, mechanical, and chemical nociception but is not essential for hair-cell transduction. Neuron 50: 277-289. 
Lee KP, So I, Kim KW (2003a). TRPC4 might not be involved in the generation of slow waves. Biophys J 84: 106a.

Lee YM, Kim BJ, Kim HJ, Yang DK, Zhu MH, Lee KP et al. (2003b). TRPC5 as a candidate for the nonselective cation channel activated by muscarinic stimulation in murine stomach. Am J Physiol Gastrointest Liver Physiol 284: G604-G616.

Lee KP, Jun JY, Chang IY, Suh SH, So I, Kim KW (2005). TRPC4 is an essential component of the nonselective cation channel activated by muscarinic stimulation in mouse visceral smooth muscle cells. Mol Cells 20: 435-441.

Lewinter RD, Skinner K, Julius D, Basbaum AI (2004). Immunoreactive TRPV-2 (VRL-1), a capsaicin receptor homolog, in the spinal cord of the rat. J Comp Neurol 470: 400-408.

Liu S, Qu MH, Ren W, Hu HZ, Gao N, Wang GD et al. (2008). Differential expression of canonical (classical) transient receptor potential channels in guinea pig enteric nervous system. J Comp Neurol 511: 847-862.

McKemy DD, Neuhausser WM, Julius D (2002). Identification of a cold receptor reveals a general role for TRP channels in thermosensation. Nature 416: 52-58.

McMahon SB, Wood JN (2006). Increasingly irritable and close to tears: TRPA1 in inflammatory pain. Cell 124: 1123-1125.

McNulty S, Fonfria E (2005). The role of TRPM channels in cell death. Pflugers Arch 451: 235-242.

Macpherson LJ, Geierstanger BH, Viswanath V, Bandell M, Eid SR, Hwang S et al. (2005). The pungency of garlic: activation of TRPA1 and TRPV1 in response to allicin. Curr Biol 15: 929-934.

de Man JG, Boeckx S, Anguille S, de Winter BY, de Schepper HU, Herman AG et al. (2008). Functional study on TRPV1-mediated signalling in the mouse small intestine: involvement of tachykinin receptors. Neurogastroenterol Motil 20: 546-556.

Margolskee RF, Dyer J, Kokrashvili Z, Salmon KS, Ilegems E, Daly K et al. (2007). T1R3 and gustducin in gut sense sugars to regulate expression of $\mathrm{Na}+$-glucose cotransporter 1. Proc Natl Acad Sci USA 104: 15075-15080.

Matthews PJ, Aziz Q, Facer P, Davis JB, Thompson DG, Anand P (2004). Increased capsaicin receptor TRPV1 nerve fibres in the inflamed human oesophagus. Eur J Gastroenterol Hepatol 16: 897-902.

Miranda A, Nordstrom E, Mannem A, Smith C, Banerjee B, Sengupta JN (2007). The role of transient receptor potential vanilloid 1 in mechanical and chemical visceral hyperalgesia following experimental colitis. Neuroscience 148: 1021-1032.

Montell C, Rubin GM (1989). Molecular characterization of the Drosophila trp locus: a putative integral membrane protein required for phototransduction. Neuron 2: 1313-1323.
Morroni M, Cangiotti AM, Cinti S (2007). Brush cells in the human duodenojejunal junction: an ultrastructural study. J Anat 211: 125-131.

Munsch T, Freichel M, Flockerzi V, Pape HC (2003). Contribution of transient receptor potential channels to the control of GABA release from dendrites. Proc Natl Acad Sci USA 100: 16065-16070.

Muraki K, Iwata Y, Katanosaka Y, Ito T, Ohya S, Shigekawa M et al. (2003). TRPV2 is a component of osmotically sensitive cation channels in murine aortic myocytes. Circ Res 93: 829-838.

Mustafa S, Oriowo M (2005). Cooling-induced contraction of the rat gastric fundus: mediation via transient receptor potential (TRP) cation channel TRPM8 receptor and Rho-kinase activation. Clin Exp Pharmacol Physiol 32: 832-838.

Nadler MJ, Hermosura MC, Inabe K, Perraud AL, Zhu Q, Stokes AJ et al. (2001). LTRPC7 is a Mg.ATP-regulated divalent cation channel required for cell viability. Nature 411: 590-595.

Nagata K, Duggan A, Kumar G, Garcia-Anoveros J (2005). Nociceptor and hair cell transducer properties of TRPA1, a channel for pain and hearing. J Neurosci 25: 4052-4061.

Neeper MP, Liu Y, Hutchinson TL, Wang Y, Flores CM, Qin N (2007). Activation properties of heterologously expressed mammalian TRPV2: evidence for species dependence. J Biol Chem 282: 15894-15902.

Nijenhuis T, Hoenderop JG, Bindels RJ (2005). TRPV5 and TRPV6 in $\mathrm{Ca}(2+)$ (re)absorption: regulating $\mathrm{Ca}(2+)$ entry at the gate. Pflugers Arch 451: 181-192.

Nilius B (2007). TRP channels in disease. Biochim Biophys Acta 1772: 805-812.

Nilius B, Voets T (2005). TRP channels: a TR(I)P through a world of multifunctional cation channels. Pflugers Arch 451: 1-10.

Nilius B, Voets T (2008). A TRP channel-steroid marriage. Nat Cell Biol 10: 1383-1384.

Nozawa Y, Nishihara K, Yamamoto A, Nakano M, Ajioka H, Matsuura N (2001). Distribution and characterization of vanilloid receptors in the rat stomach. Neurosci Lett 309: 33-36.

Nozawa K, Kawabata-Shoda E, Doihara H, Kojima R, Okada H, Mochizuki S et al. (2009). TRPA1 regulates gastrointestinal motility through serotonin release from enterochromaffin cells. Proc Natl Acad Sci USA 106: 3408-3413.

O'Neil RG, Heller S (2005). The mechanosensitive nature of TRPV channels. Pflugers Arch 451: 193-203.

Ordog T, Ward SM, Sanders KM (1999). Interstitial cells of cajal generate electrical slow waves in the murine stomach. J Physiol 518: 257-269.

Otsuguro K, Tang J, Tang Y, Xiao R, Freichel M, Tsvilovskyy V et al. (2008). Isoform-specific inhibition of TRPC4 channel by phosphatidylinositol 4,5-bisphosphate. J Biol Chem 283: 10026-10036. 
Owsianik G, D'Hoedt D, Voets T, Nilius B (2006). Structure-function relationship of the TRP channel superfamily. Rev Physiol Biochem Pharmacol 156: 61-90.

Peier AM, Moqrich A, Hergarden AC, Reeve AJ, Andersson DA, Story GM et al. (2002). A TRP channel that senses cold stimuli and menthol. Cell 108: 705-715.

Penuelas A, Tashima K, Tsuchiya S, Matsumoto K, Nakamura T, Horie S et al. (2007). Contractile effect of TRPA1 receptor agonists in the isolated mouse intestine. Eur J Pharmacol 576: 143-150.

Phillis BD, Martin CM, Kang D, Larsson H, Lindstrom EA, Martinez V et al. (2009). Role of TRPV1 in high-threshold rat colonic splanchnic afferents is revealed by inflammation. Neurosci Lett 459: 57-61.

Pilichiewicz AN, Horowitz M, Russo A, Maddox AF, Jones KL, Schemann M et al. (2007). Effects of Iberogast on proximal gastric volume, antropyloroduodenal motility and gastric emptying in healthy men. Am J Gastroenterol 102: 1276-1283.

Purhonen AK, Louhivuori LM, Kiehne K, Kerman KE, Herzig KH (2008). TRPA1 channel activation induces cholecystokinin release via extracellular calcium. FEBS Lett 582: 229-232.

Quamme GA (2008). Recent developments in intestinal magnesium absorption. Curr Opin Gastroenterol 24: 230-235.

Ramsey IS, Delling M, Clapham DE (2006). An introduction to TRP channels. Annu Rev Physiol 68: 619-647.

Raybould HE, Tache Y (1989). Capsaicin-sensitive vagal afferent fibers and stimulation of gastric acid secretion in anesthetized rats. Eur J Pharmacol 167: 237-243.

Rohacs T (2007). Regulation of TRP channels by PIP(2). Pflugers Arch 453: 753-762.

Roka R, Wittmann T, Bueno L (2008). Altered protease signalling in the gut: a novel pathophysiological factor in irritable bowel syndrome. Neurogastroenterol Motil 20: 853-856.

Rong W, Hillsley K, Davis JB, Hicks G, Winchester WJ, Grundy D (2004). Jejunal afferent nerve sensitivity in wild-type and TRPV1 knockout mice. J Physiol 560: 867-881.

Rozengurt E, Sternini C (2007). Taste receptor signaling in the mammalian gut. Curr Opin Pharmacol 7: $557-562$.

Sanger GJ (2007). Endocannabinoids and the gastrointestinal tract: what are the key questions? Br J Pharmacol 152: 663-670.

Sbarbati A, Osculati F (2005a). A new fate for old cells: brush cells and related elements. J Anat 206: 349-358.

Sbarbati A, Osculati F (2005b). The taste cell-related diffuse chemosensory system. Prog Neurobiol 75: 295-307.
Schaefer M (2005). Homo- and heteromeric assembly of TRP channel subunits. Pflugers Arch 451: 35-42.

Schemann M, Mazzuoli G (2010). Multifunctional mechanosensitive neurons in the enteric nervous system. Auton Neurosci 153: 21-25.

Schemann M, Michel K, Zeller F, Hohenester B, Ruhl A (2006). Region-specific effects of STW 5 (Iberogast) and its components in gastric fundus, corpus and antrum. Phytomedicine 13 (Suppl. 5): 90-99.

Schmidt B, Hammer J, Holzer P, Hammer HF (2004). Chemical nociception in the jejunum induced by capsaicin. Gut 53: 1109-1116.

Schmitz C, Perraud AL, Johnson CO, Inabe K, Smith MK, Penner R et al. (2003). Regulation of vertebrate cellular Mg2+ homeostasis by TRPM7. Cell 114: 191-200.

Sengupta JN, Snider A, Su X, Gebhart GF (1999). Effects of kappa opioids in the inflamed rat colon. Pain 79: 175-185.

Shimizu T, Owsianik G, Freichel M, Flockerzi V, Nilius B, Vennekens R (2009). TRPM4 regulates migration of mast cells in mice. Cell Calcium 45: 226-232.

Sipe WE, Brierley SM, Martin CM, Phillis BD, Cruz FB, Grady EF et al. (2008). Transient receptor potential vanilloid 4 mediates protease activated receptor 2-induced sensitization of colonic afferent nerves and visceral hyperalgesia. Am J Physiol Gastrointest Liver Physiol 294: G1288-G1298.

Smith PL, Maloney KN, Pothen RG, Clardy J, Clapham DE (2006). Bisandrographolide from Andrographis paniculata activates TRPV4 channels. J Biol Chem 281: 29897-29904.

Smith TK, Spencer NJ, Hennig GW, Dickson EJ (2007). Recent advances in enteric neurobiology: mechanosensitive interneurons. Neurogastroenterol Motil 19: 869-878.

Sternini C, Anselmi L, Rozengurt E (2008).

Enteroendocrine cells: a site of 'taste' in gastrointestinal chemosensing. Curr Opin Endocrinol Diabetes Obes 15: 73-78.

Story GM, Peier AM, Reeve AJ, Eid SR, Mosbacher J, Hricik TR et al. (2003). ANKTM1, a TRP-like channel expressed in nociceptive neurons, is activated by cold temperatures. Cell 112: 819-829.

Strubing C, Krapivinsky G, Krapivinsky L, Clapham DE (2001). TRPC1 and TRPC5 form a novel cation channel in mammalian brain. Neuron 29: 645-655.

Strubing C, Krapivinsky G, Krapivinsky L, Clapham DE (2003). Formation of novel TRPC channels by complex subunit interactions in embryonic brain. J Biol Chem 278: 39014-39019.

Sugiuar T, Bielefeldt K, Gebhart GF (2004). TRPV1 function in mouse colon sensory neurons is enhanced by metabotropic 5-hydroxytryptamine receptor activation. J Neurosci 24: 9521-9530. 
Suzuki M, Mizuno A, Kodaira K, Imai M (2003a). Impaired pressure sensation in mice lacking TRPV4. J Biol Chem 278: 22664-22668.

Suzuki M, Watanabe Y, Oyama Y, Mizuno A, Kusano E, Hirao A et al. (2003b). Localization of mechanosensitive channel TRPV4 in mouse skin. Neurosci Lett 353: 189-192.

Suzuki Y, Landowski CP, Hediger MA (2008). Mechanisms and regulation of epithelial Ca2+ absorption in health and disease. Annu Rev Physiol 70: 257-271.

Talavera K, Yasumatsu K, Voets T, Droogmans G, Shigemura N, Ninomiya Y et al. (2005). Heat activation of TRPM5 underlies thermal sensitivity of sweet taste. Nature 438: 1022-1025.

Talavera K, Gees M, Karashima Y, Meseguer VM, Vanoirbeek JA, Damann N et al. (2009). Nicotine activates the chemosensory cation channel TRPA1. Nat Neurosci 12: 1293-1299.

Tominaga M, Caterina MJ, Malmberg AB, Rosen TA, Gilbert H, Skinner K et al. (1998). The cloned capsaicin receptor integrates multiple pain-producing stimuli. Neuron 21: 531-543.

Torihashi S, Fujimoto T, Trost C, Nakayama S (2002). Calcium oscillation linked to pacemaking of interstitial cells of Cajal: requirement of calcium influx and localization of TRP4 in caveolae. J Biol Chem 277: 19191-19197.

Tsavaler L, Shapero MH, Morkowski S, Laus R (2001). Trp-p8, a novel prostate-specific gene, is up-regulated in prostate cancer and other malignancies and shares high homology with transient receptor potential calcium channel proteins. Cancer Res 61: 3760-3769.

Tsvilovskyy VV, Zholos AV, Aberle T, Philipp SE, Dietrich A, Zhu MX et al. (2009). Deletion of TRPC4 and TRPC6 in mice impairs smooth muscle contraction and intestinal motility in vivo. Gastroenterology 137: 1415-1424.

Venkatachalam K, van Rossum DB, Patterson RL, Ma HT, Gill DL (2002). The cellular and molecular basis of store-operated calcium entry. Nat Cell Biol 4: E263-E272.

Venkatachalam K, Zheng F, Gill DL (2003). Regulation of canonical transient receptor potential (TRPC) channel function by diacylglycerol and protein kinase C. J Biol Chem 278: 29031-29040.

Vennekens R, Olausson J, Meissner M, Bloch W, Mathar I, Philipp SE et al. (2007). Increased IgE-dependent mast cell activation and anaphylactic responses in mice lacking the calcium-activated nonselective cation channel TRPM4. Nat Immunol 8: 312-320.

Vennekens R, Owsianik G, Nilius B (2008). Vanilloid transient receptor potential cation channels: an overview. Curr Pharm Des 14: 18-31.
Voets T, Droogmans G, Wissenbach U, Janssens A, Flockerzi V, Nilius B (2004). The principle of temperature-dependent gating in cold- and heat-sensitive TRP channels. Nature 430: 748-754.

Vriens J, Watanabe H, Janssens A, Droogmans G, Voets T, Nilius B (2004). Cell swelling, heat, and chemical agonists use distinct pathways for the activation of the cation channel TRPV4. Proc Natl Acad Sci USA 101: 396-401.

Vriens J, Nilius B, Vennekens R (2008). Herbal Compounds and Toxins Modulating TRP Channels. Curr Neuropharmacol 6: 79-96.

Vriens J, Appendino G, Nilius B (2009). Pharmacology of vanilloid transient receptor potential cation channels. Mol Pharmacol 75: 1262-1279.

Walker RL, Hume JR, Horowitz B (2001). Differential expression and alternative splicing of TRP channel genes in smooth muscles. Am J Physiol Cell Physiol 280: C1184-C1192.

Walker RL, Koh SD, Sergeant GP, Sanders KM, Horowitz B (2002). TRPC4 currents have properties similar to the pacemaker current in interstitial cells of Cajal. Am J Physiol Cell Physiol 283: C1637-C1645.

Ward SM, Beckett EA, Wang X, Baker F, Khoyi M, Sanders KM (2000). Interstitial cells of Cajal mediate cholinergic neurotransmission from enteric motor neurons. J Neurosci 20: 1393-1403.

Ward SM, Bayguinov J, Won KJ, Grundy D, Berthoud HR (2003). Distribution of the vanilloid receptor (VR1) in the gastrointestinal tract. J Comp Neurol 465: 121-135.

Watanabe H, Davis JB, Smart D, Jerman JC, Smith GD, Hayes P et al. (2002). Activation of TRPV4 channels (hVRL-2/mTRP12) by phorbol derivatives. J Biol Chem 277: $13569-13577$.

Watanabe H, Vriens J, Prenen J, Droogmans G, Voets T, Nilius B (2003). Anandamide and arachidonic acid use epoxyeicosatrienoic acids to activate TRPV4 channels. Nature 424: 434-438.

van den Wijngaard RM, Klooker TK, Welting O, Stanisor OI, Wouters MM, van der Coelen D et al. (2009). Essential role for TRPV1 in stress-induced (mast cell-dependent) colonic hypersensitivity in maternally separated rats. Neurogastroenterol Motil 21: 1107-e94. DOI: 10.1111/j.1365-2982.2009.01339.x.

Williamson S, Pompolo S, Furness JB (1996). GABA and nitric oxide synthase immunoreactivities are colocalized in a subset of inhibitory motor neurons of the guinea-pig small intestine. Cell Tissue Res 284: 29-37.

Winston J, Shenoy M, Medley D, Naniwadekar A, Pasricha PJ (2007). The vanilloid receptor initiates and maintains colonic hypersensitivity induced by neonatal colon irritation in rats. Gastroenterology 132: 615-627.

Wong GY, Gavva NR (2009). Therapeutic potential of vanilloid receptor TRPV1 agonists and antagonists as analgesics: recent advances and setbacks. Brain Res Rev 60: 267-277. 
Wood JD (2008). Enteric nervous system: reflexes, pattern generators and motility. Curr Opin Gastroenterol 24: 149-158.

Wrigley PJ, Jeong HJ, Vaughan CW (2009). Primary afferents with TRPM8 and TRPA1 profiles target distinct subpopulations of rat superficial dorsal horn neurones. Br J Pharmacol 157: 371-380.

Yiangou Y, Facer P, Dyer NH, Chan CL, Knowles C, Williams NS et al. (2001). Vanilloid receptor 1 immunoreactivity in inflamed human bowel. Lancet 357: 1338-1339.

Yildirim E, Birnbaumer L (2007). TRPC2: molecular biology and functional importance. Handb Exp Pharmacol 179: 53-75.

Young RL, Sutherland K, Pezos N, Brierley SM, Horowitz M, Rayner CK et al. (2009). Expression of taste molecules in the upper gastrointestinal tract in humans with and without type 2 diabetes. Gut 58: 337-346.

Yu S, Ouyang A (2009). TRPA1 in bradykinin-induced mechanical hypersensitivity of vagal $C$ fibers in guinea pig esophagus. Am J Physiol Gastrointest Liver Physiol 296: G255-G265.

Yu S, Gao G, Peterson BZ, Ouyang A (2009). TRPA1 in mast cell activation-induced long-lasting mechanical hypersensitivity of vagal afferent C-fibers in guinea pig esophagus. Am J Physiol Gastrointest Liver Physiol 297: G34-G42.

Zhang Y, Hoon MA, Chandrashekar J, Mueller KL, Cook B, Wu D et al. (2003). Coding of sweet, bitter, and umami tastes: different receptor cells sharing similar signaling pathways. Cell 112: 293-301.

Zhang L, Jones S, Brody K, Costa M, Brookes SJ (2004). Thermosensitive transient receptor potential channels in vagal afferent neurons of the mouse. Am J Physiol Gastrointest Liver Physiol 286: G983-G991.

Zhu MH, Kim TW, Ro S, Yan W, Ward SM, Koh SD et al. (2009). A Ca(2+)-activated $\mathrm{Cl}(-)$ conductance in interstitial cells of Cajal linked to slow wave currents and pacemaker activity. J Physiol 587: 4905-4918. 